Provided for non-commercial research and education use. Not for reproduction, distribution or commercial use.

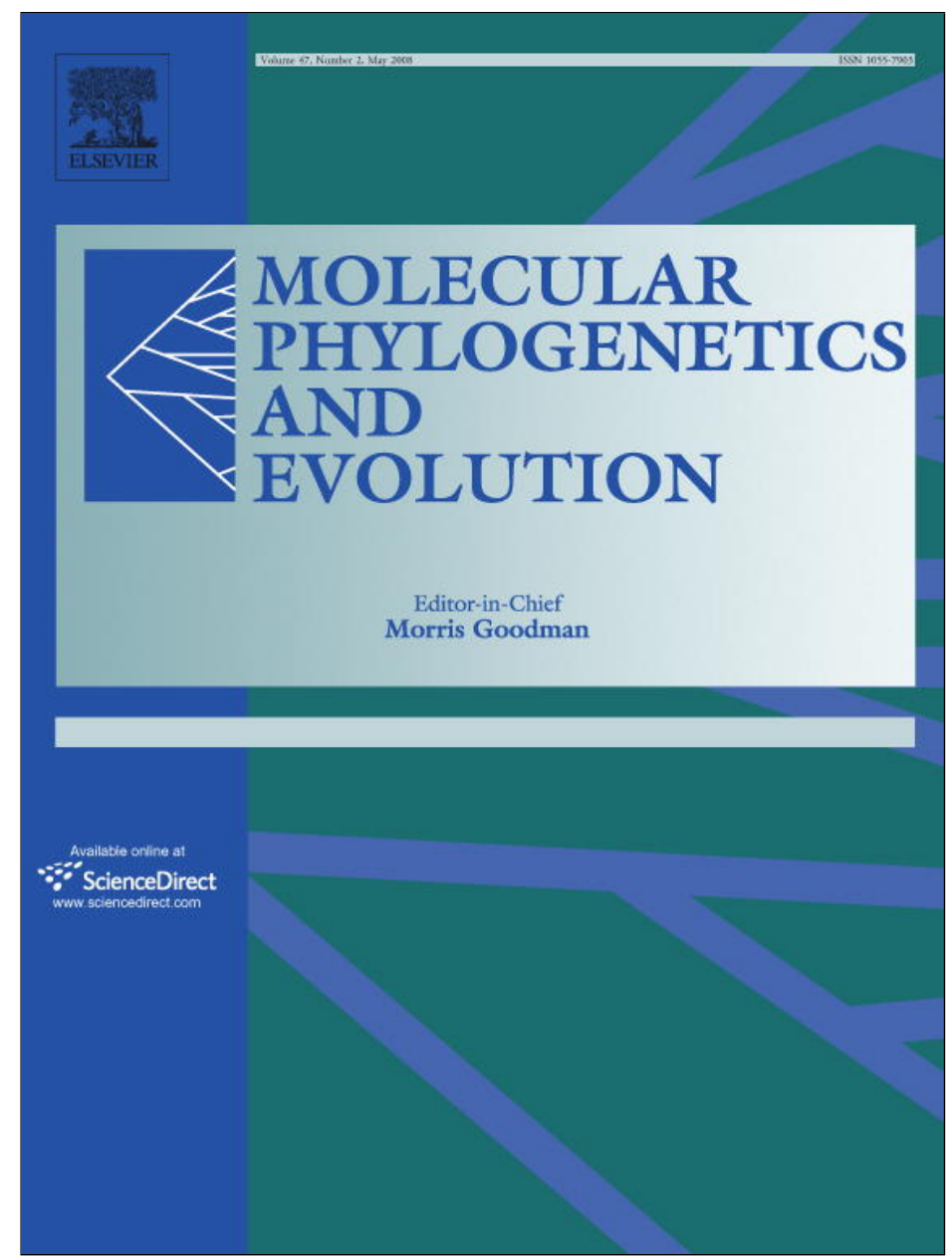

This article appeared in a journal published by Elsevier. The attached copy is furnished to the author for internal non-commercial research and education use, including for instruction at the authors institution and sharing with colleagues.

Other uses, including reproduction and distribution, or selling or licensing copies, or posting to personal, institutional or third party websites are prohibited.

In most cases authors are permitted to post their version of the article (e.g. in Word or Tex form) to their personal website or institutional repository. Authors requiring further information regarding Elsevier's archiving and manuscript policies are encouraged to visit:

http://www.elsevier.com/copyright 


\title{
Geography and host biogeography matter for understanding the phylogeography of a parasite
}

\author{
C.M. Nieberding ${ }^{\mathrm{a}, \mathrm{b}, *}$, M.-C. Durette-Desset ${ }^{\mathrm{c}}$, A. Vanderpoorten ${ }^{\mathrm{a}}$, J.C. Casanova $^{\mathrm{d}}$, \\ A. Ribas ${ }^{\mathrm{d}}$, V. Deffontaine ${ }^{\mathrm{a}, \mathrm{e}}$, C. Feliu ${ }^{\mathrm{d}}$, S. Morand ${ }^{\mathrm{e}}$, R. Libois ${ }^{\mathrm{a}}$, J.R. Michaux ${ }^{\mathrm{a}, \mathrm{e}}$ \\ ${ }^{a}$ Institute of Botany, Liège University, 4000 Sart Tilman, Belgium \\ ${ }^{\mathrm{b}}$ Institute of Biology, Leiden University, 2300 RA Leiden, The Netherlands \\ ${ }^{\mathrm{c}}$ National Museum of Natural History, 61 rue de Buffon, 75251 Paris, France \\ ${ }^{\mathrm{d}}$ Faculty of Pharmacy, Barcelona University, Av. Joan XXIII s/n, 08028 Barcelona, Spain \\ ${ }^{\mathrm{e}}$ Centre for Biology and Management of Populations, International Campus of Baillarguet CS 30016, 34988 Montferrier-sur-Lez, France
}

Received 9 May 2007; revised 15 January 2008; accepted 24 January 2008

Available online 2 February 2008

\begin{abstract}
The co-evolution between hosts and parasites has long been recognized as a fundamental driver of macro-evolutionary patterns of diversification. The effect of co-differentiation on parasite diversification is, however, often confounded by underlying geographic patterns of host distribution. In order to disentangle the confounding effects of allopatric versus host speciation, the mitochondrial cytochrome $b(c y t b)$ gene was sequenced in seventy individuals of the parasitic nematode genus Heligmosomoides sampled in the six Apodemus mice species common in the western Palearctic region. The nuclear internal transcribed spacers (ITS) 1 and 2 were also sequenced in fifteen parasites to confirm the mitochondrial data. All lineages differentiated according to a geographic pattern and independently from the sampled host species. This suggests that host speciation did not involve concurrent parasite speciation. However, the geographic distribution range of some parasite lineages mirrors that of $A$. sylvaticus lineages in SW Europe, and that of A. flavicollis lineages in the Balkans and in the Middle East. Thus, regional co-differentiation likely occurred between the parasite and the two sister Apodemus hosts in different parts of their distribution range. We suggest that differences in regional abundances of $A$. sylvaticus and $A$. flavicollis are responsible for generating this pattern of regional co-differentiation. This study highlights the importance of integrating both geography and biogeographic information from potential hosts to better understand their parasite phylogeography.
\end{abstract}

(c) 2008 Elsevier Inc. All rights reserved.

Keywords: Biogeography; Comparative phylogeography; Co-differentiation; Common differentiation; Co-speciation; Host; Parasite; Apodemus; Heligmosomoides; Nematode; Wood mouse; Yellow-necked mouse; Palearctic; Europe; Middle-East

\section{Introduction}

Interactions among species are a fundamental driver of macro-evolutionary patterns of diversification. One of the most relevant examples of interspecific interactions is the co-evolutionary pattern apparent between hosts and

\footnotetext{
${ }^{*}$ Corresponding author. Present address: Institute of Biology, Leiden University, Kaiserstraat, 63, 2311 GP Leiden, The Netherlands. Fax: +31 715274900 .

E-mail address: caroline.nieberding@ulg.ac.be (C.M. Nieberding).
}

parasites. In host-parasite interactions, co-speciation, i.e., the joint speciation between host and its parasite, can arise if the two organisms share a common evolutionary history, so that the parasite follows the speciation events of its host (Page, 2003). Common history is favoured by traits that strengthen the host-parasite relationship, such as a high level of specificity between the host and its parasite and vertical transmission of parasites among hosts (Page, 2003; Nieberding and Olivieri, 2007). At the phylogenetic level, common history between two taxa remains so far best observed by congruent phylogenetic trees (Huelsenbeck et al., 1997; Charleston and Perkins, 2006). 
Yet, co-speciation is an ongoing process; thus co-differentiation between lineages of a host and its parasite species should be already detectable at the intraspecific level. Since speciation often takes place between allopatric lineages (Schluter, 2001), co-differentiating lineages of a host species and its parasite are expected to be allopatric and the corresponding host and parasite lineages to cover similar geographic areas (Nieberding et al., 2004). In other words, at the intraspecific level, we suggest that a common history is best observed between a host and its parasite whose genetic lineages cover similar allopatric areas (Nieberding et al., 2004; Nieberding and Olivieri, 2007). In this framework, we previously compared the phylogeographic patterns of the wood mouse Apodemus sylvaticus Linnaeus 1758 (Muridae, Rodentia), and one of its parasites, the nematode Heligmosomoides polygyrus (Dujardin, 1845) (Heligmosomidae, Nematoda) over their continental and insular distribution ranges (Nieberding et al., 2004, 2006). $H$. polygyrus is a specific and direct (i.e., without intermediate host) parasite of rodent hosts of the Apodemus Kaup, 1829 genus in the western Palearctic region (Durette-Desset, 1968; N'Zobadila et al., 1996a). H. polygyrus reproduces exclusively sexually and its first larval stages are free-living, requiring 4 to 6 days to become infective. Host infection occurs following ingestion of parasitized faeces. Adult parasites live in the intestine and produce eggs in the host faeces about nine days after ingestion, and during up to nine months (Ehrenford, 1954; N'Zobadila et al., 1996b).

$H$. polygyrus and $A$. sylvaticus were shown to display similar genetic and geographic lineages over south Western Europe (Spain, France and Belgium), Italy and North Africa. Moreover, both species display correlated values of genetic diversity and divergence within and between lineages that share the same geographic range (Nieberding et al., 2004). These shared traits showed that $H$. polygyrus and A. sylvaticus displayed a common evolutionary history in the south western Palearctic region over the last 2 millions years, i.e., co-differentiated. We suggested that the common history between the two species might lead to co-speciation over a longer time period and/or larger distribution ranges (Nieberding et al., 2004, 2005b, 2006).

The aim of the present study is to determine whether common differentiation between $H$. polygyrus and $A$. sylvaticus could be observed between parasites from the Heligmosomoides genus and other Apodemus hosts, and test whether parasite differentiation could be attributed mostly to host or to geography. Our parasite sampling was extended to five additional Apodemus species, which are commonly sympatric with $A$. sylvaticus in the western Palearctic region. We expect that, if there is co-speciation at a higher taxonomic level between the two taxa, the genetic lineages of Heligmosomoides parasites will be specific to different Apodemus host species and thus segregate accordingly to the Apodemus species on which they were sampled. In other words, each Heligmosomoides lineage would be associated to a particular host species, whatever the geographic origin of the parasites. Alternatively, if co-speciation did not occur at a higher taxonomic level, the genetic lineages of Heligmosomoides will rather segregate according to the different geographic regions sampled (allopatric divergence). In other words, each Heligmosomoides lineage will be linked to a particular geographic region, whatever the sampled host species might be.

Several pieces of information indicate that the scenario of strict co-speciation between Heligmosomoides and Apodemus is not the most likely. First, the parasites sampled in the Balkans (former Yugoslavia, Slovenia, Greece, Romania,...) and in Turkey segregated in two distinct genetic lineages (not forming sister taxa) while the corresponding populations of $A$. sylvaticus remained undifferentiated from the Italian ones (Michaux et al., 2003; Nieberding et al., 2004, 2006). This suggests that the history of formation of the parasite lineages might not be tightly linked to A. sylvaticus hosts in the eastern part of their distribution range. This would prevent the two taxa from showing a strict co-speciation pattern over a longer time period and a larger distribution range. Second, common differentiation between the parasite and A. sylvaticus in south Western Europe was explained by the high level of past and current specificity of the parasite on A. sylvaticus (Nieberding et al., 2004). However, field data as well as cumulative bibliographic information highlighted that host specificity of $H$. polygyrus might be less strong than previously supposed (e.g., Durette-Desset, 1968; N'Zobadila et al., 1996a,b; this study). Horizontal transmission of Heligmosomoides parasites between different sympatric Apodemus host species (see Fig. 1) could prevent the emergence of a co-speciation pattern over longer time periods. Third, parasite lineages from the Balkans and the Middle East rather mirror the geographic differentiation of A. flavicollis or of A. mystacinus lineages (Michaux et al., 2004, 2005a; Nieberding et al., 2006). The other Apodemus species present in the western Palearctic are less likely to have acted upon Heligmosomoides differentiation. Indeed, A. alpicola and $A$. uralensis display a limited past and present distribution range (Fig. 1). Moreover, fossil records and genetic analysis reveal that $A$. agrarius reached the western Palearctic within the last 10,000 years from the Eastern Palearctic (Kowalski, 2001), which excludes this species as a potential host for H. polygyrus in Eastern Europe or in the Middle East during the Quaternary. Thus A. flavicollis and $A$. mystacinus will be tested as alternative relevant long-term hosts in the Eastern part of the parasite distribution range.

To discriminate between the alternative hypotheses of co-speciation versus geographic differentiation, we looked for the presence of parasites of the Heligmosomoides genus in all Apodemus species common in the western Palearctic region: A. sylvaticus, A. flavicollis Melchior1834, A. mystacinus Danford and Alston, 1877, A. uralensis (Pallas, 1811) and A. alpicola Heinrich, 1952 from the Sylvaemus subgenus, as well as A. agrarius (Pallas, 1771) from the 

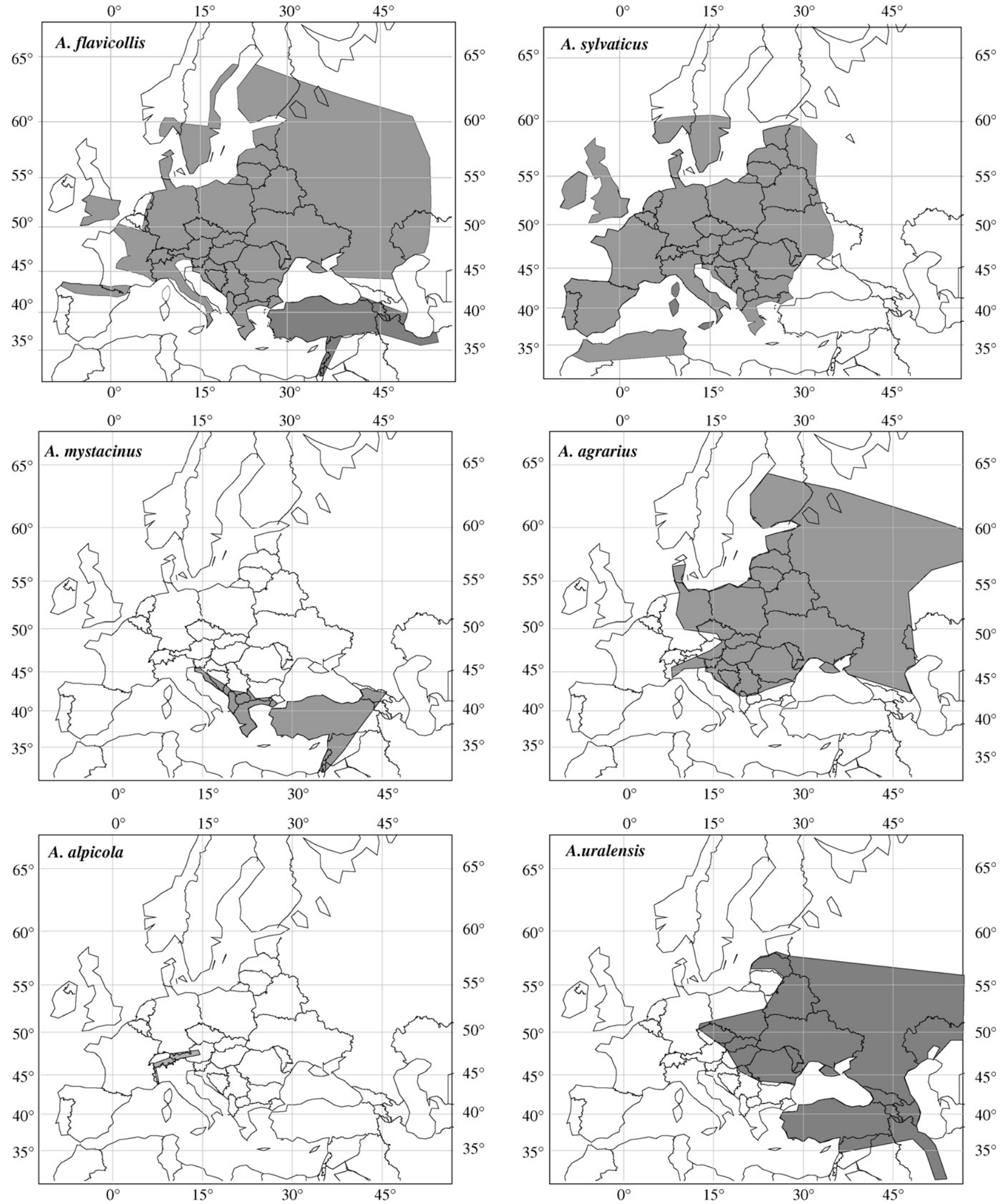

Fig. 1. Distribution range of the six Apodemus species common in the south western Palearctic (Europe, Middle East and North Africa), according to updated information found in Panteleyev (1998) and Mitchell-Jones et al. (1999).

Apodemus subgenus (Filippucci et al., 2002; Michaux et al., 2002). Multiple Heligmosomoides species were described in Apodemus over continental Europe, including H. skrjarbini
Schulz (1926) and H. azerbaidjani Schachnazarova (1949) in $A$. sylvaticus, but they all recently fell into synonymy with $H$. polygyrus (Dujardin, 1845) (see e.g., Tenora 
et al., 2003). Four supplementary Heligmosomoides species have been described in the western Palearctic region on Arvicolinae (H. glareoli Baylis, 1928 in Clethrionomys glareolus, H. laevis (Dujardin, 1845) Linstow, 1878 in Arvicola subterraneus, and $H$. tatricus Erhardova, 1955 in Microtus nivalis) and Cricetidae (H. travassosi Schulz,1926 in Cricetus cricetus) rodent hosts. Yet, the host range of each parasite lineage is not defined, and no genetic data are available, so that the species determinations and their reorganization have been based on morphological data for which diagnostic characters remain limited. Nevertheless, it reveals that Heligmosomoides parasites display some level of variation in the studied area. The Heligmosomoides individuals found in all Apodemus species were sequenced for the mitochondrial cytochrome b $(c y t b)$ gene. Because mitochondrial genes do not necessarily convey the evolutionary history of species (Ballard and Whitlock, 2004), we also sequenced the nuclear non coding ITS1 and ITS2 regions of a sub-sample of individuals, in order to confirm the accuracy of the mtDNA-based results. The parasite consensus phylogenetic tree was then compared to the Apodemus phylogeny and phylogeographies, to determine whether co-speciation or geographic differentiation was most likely responsible for the observed pattern of parasite divergence. Finally, we dated the divergence times among the parasite lineages.

\section{Materials and methods}

\subsection{Collection of samples}

A total of seventy Heligmosomoides adult individuals (from twenty-three localities) were sampled on $A$. sylvaticus, A. flavicollis, A. mystacinus, A. alpicola, A. uralensis or $A$. agrarius, throughout the south western Palearctic region. Forty of these were obtained in previous studies (Nieberding et al., 2004, 2005b, 2006); the other thirty Heligmosomoides individuals sequenced here were sampled from twelve populations in one or more Apodemus species (Czech Republic, Slovakia, Romania, Russia, Austria and Poland) (see Table 1 and Fig. 2 for detailed sampling). Our sampling includes representative samples from all previously published genetic lineages for $H$. polygyrus, except the northern European one (present in Ireland and Denmark, see Nieberding et al., 2005b): south western European (Spain, France and Belgium), Moroccan, Italian, Sicilian, Balkan (Austria, Czech Republic, Greece, Slovakia, Slovenia and Romania) and Turkish lineages. This sampling includes Heligmosomoides individuals from all common Apodemus species in the south western Palearctic, whose distribution ranges partially overlap (Fig. 1). Parasites from each genetic group were identified at the genus level by morphological determination; all hosts were identified at the species level either by morphological determination or by using species-specific markers of $A$. sylvaticus, A. flavicollis and A. alpicola (Michaux et al., 2001).

\subsection{Sequence data}

Heligmosomoides DNA was extracted from single individuals using the $\mathrm{NaOH}$ digestion protocol of Blaxter et al. (1998). Each nematode was incubated overnight in $20 \mu \mathrm{l}$ of $0.25 \mathrm{M} \mathrm{NaOH}$. The solution was then heated three min at $99{ }^{\circ} \mathrm{C}$. After the solution had cooled to room temperature, $4 \mu \mathrm{l}$ of $1 \mathrm{M}$ of $\mathrm{HCl}, 10 \mu \mathrm{l}$ of $0.5 \mathrm{M}$ of Tris- $\mathrm{HCl}$ ( $\mathrm{pH} 8.0$ ) and $5 \mu \mathrm{l}$ of $2 \%$ of Triton $\mathrm{X}-100$ were added to the solution. The solution was mixed and finally heated for three more min at $99^{\circ} \mathrm{C}$. Six hundred ninety (690) bp of $c y t b$ gene were amplified by the polymerase chain reaction (PCR) using the specific primers cytb.1Fc (5'-GRAA TTTTGGTAGTATRTTRG-3') and cytb.1R (5'-AGMA CGYAAAATWGYAWAAGC-3') in all new individuals, except Czech and Russian ones, for which the primer cytb.1F (5'-KCWGTRGTTATYACTAG-3') was used with the primer cytb.1R to amplify the last $400 \mathrm{bp}$ of the $690 \mathrm{bp}$ of the $c y t b$ gene. The total length of the nuclear non coding internal transcribed spacers 1 and 2 (ITS1 and ITS2, 500 and $498 \mathrm{bp}$, respectively) were amplified by PCR using the specific primers ITS1.1F (5'-ACAGT TCAATCGCAATGGC-3') and ITS2.1R (5'-TTAGTTT CTTTTCCTCCGCT-3') designed for this study. Amplification reactions of $c y t b$ and ITS sequences were carried out in $25 \mu \mathrm{L}$ including $0.175 \mu \mathrm{L}$ of $100 \mu \mathrm{M}$ of the forward and reverse primers, $2 \mu \mathrm{L}$ of DMSO, $2 \mu \mathrm{L}$ of $1 \mathrm{mM}$ of $\mathrm{dNTP}, 2.5 \mu \mathrm{L}$ of $10 \times$ reaction buffer, $0.2 \mu \mathrm{L}$ of Qiagen Taq DNA polymerase, $16.95 \mu \mathrm{L}$ of ultrapure water and $1 \mu \mathrm{L}$ of DNA solution. Amplifications were performed in a Labover PTC100 Thermal Cycler using 40 cycles $(1 \mathrm{~min}$ at $94{ }^{\circ} \mathrm{C}, 1 \mathrm{~min}$ at $48^{\circ} \mathrm{C}$ and $1 \mathrm{~min} 30 \mathrm{~s}$ at $72^{\circ} \mathrm{C}$ for the cyt $b$ amplification; $1 \mathrm{~min}$ at $94^{\circ} \mathrm{C}, 1 \mathrm{~min}$ at $53{ }^{\circ} \mathrm{C}$ and $3 \mathrm{~min}$ at $72{ }^{\circ} \mathrm{C}$ for the ITS amplification) with a final extension cycle of $10 \mathrm{~min}$ at $72{ }^{\circ} \mathrm{C}$. Four PCRs were performed for each individual. PCR products were concentrated, then purified using the Ultrafree DA Amicon Kit (Millipore) and directly sequenced. Both strands were sequenced using a BigDye Terminator sequencing kit on an ABI 310 automated sequencer (Applied Biosystems) and the primers used for amplification reactions.

\subsection{Phylogenetic analyses}

The $c y t b$ gene data matrix of Heligmosomoides comprised 70 Heligmosomoides sequences. Heligmosomoides kurilensis kobayashi Asakawa and Ohbayashi, 1986 sampled on Apodemus speciosus in Japan, and Heligmonoides $s p$ sampled on Mus domesticus in Syria were used as outgroups. Heligmosomoides et Heligmonoides belong to the same superfamily (Heligmosomoidea) but to two different families, Heligmosomidae in the case of Heligmosomoides and Heligmonellidae in the case of Heligmonoides. The sequences from the ITS1 and ITS2 were combined and comprised 15 Heligmosomoides sequences; Heligmosomoides kurilensis kobayashi was used as outgroup. 
Table 1

Geographical distribution, tissue collection codes, host species, and EMBL Accession Numbers of Heligmosomoides individuals (690 bp of $c y t$ bene and $988 \mathrm{bp}$ of the ITS regions)

\begin{tabular}{|c|c|c|c|c|c|c|c|}
\hline \multirow[t]{2}{*}{ Host } & \multirow[t]{2}{*}{ Country } & \multirow[t]{2}{*}{ Region } & \multirow[t]{2}{*}{ Geo. Code } & \multirow[t]{2}{*}{ Samp. Code } & \multicolumn{3}{|c|}{ EMBL Accession Numbers ${ }^{a}$} \\
\hline & & & & & cytb & ITS1 & ITS2 \\
\hline \multirow{32}{*}{ A. sylvaticus } & \multirow[t]{2}{*}{ Spain } & \multirow[t]{2}{*}{ Catalonia } & $\mathrm{Sp}$ & Syl.Sp & AJ608806 & & \\
\hline & & & $\mathrm{Sp}$ & Syl.Sp & AJ608810 & AM409063 & AM409079 \\
\hline & \multirow[t]{2}{*}{ France } & \multirow[t]{2}{*}{ Loiret } & $\mathrm{Fr}$ & Syl.Fr & AJ608848 & & \\
\hline & & & $\mathrm{Fr}$ & Syl.Fr & AJ608829 & & \\
\hline & \multirow[t]{2}{*}{ Belgium } & \multirow[t]{2}{*}{ Liege } & $\mathrm{Be}$ & Syl.Be & AJ608868 & & \\
\hline & & & $\mathrm{Be}$ & Syl.Be & AJ608860 & & \\
\hline & \multirow[t]{5}{*}{ Morocco } & Haut Atlas & Mo & Syl.Mo & AJ971147 & AM409064 & AM409080 \\
\hline & & & Mo & Syl.Mo & AJ971148 & AM409065 & AM409081 \\
\hline & & & Mo & Syl.Mo & AJ971149 & & \\
\hline & & & Mo & Syl.Mo & AJ971151 & & \\
\hline & & & Mo & Syl.Mo & AJ971152 & & \\
\hline & Turkey & Ayder & Tul & Syl.Tu1 & AJ971209 & & \\
\hline & & & Tul & Syl.Tu1 & AJ971210 & & \\
\hline & & Bozdag & Tu2 & Syl.Tu2 & AJ971213 & AM409075 & AM409091 \\
\hline & & & Tu2 & Syl.Tu2 & AJ971211 & AM409076 & AM409092 \\
\hline & & Ortan & Tu3 & Syl.Tu3 & AJ971215 & & \\
\hline & & & Tu3 & Syl.Tu3 & AJ971217 & & \\
\hline & Italy & Calabria & It2 & Syl.It2 & AJ608889 & AM409073 & AM409089 \\
\hline & & & It2 & Syl.It2 & AJ608884 & & \\
\hline & & & It2 & Syl.It2 & AJ608885 & & \\
\hline & & Sicily & It3 & Syl.It3 & AJ608874 & & \\
\hline & & & It3 & Syl.It3 & AJ608875 & & \\
\hline & & & It3 & Syl.It3 & AJ608876 & & \\
\hline & & & It3 & Syl.It3 & AJ608878 & & \\
\hline & & & It3 & Syl.It3 & AJ608879 & & \\
\hline & & Tuscany & It4 & Syl.It4 & AJ608880 & & \\
\hline & Czech Republic & Not known & $\mathrm{Cz}$ & Syl.Cz & AM408285 & & \\
\hline & Greece & Crete & Gr1 & Syl.Gr1 & AJ608914 & & \\
\hline & & & Gr1 & Syl.Gr1 & AJ608909 & AM409066 & AM409082 \\
\hline & & & Gr1 & Syl.Gr1 & AJ608913 & & \\
\hline & & Peloponnese & Gr2 & Syl.Gr2 & AJ608916 & & \\
\hline & & & Gr2 & Syl.Gr2 & AJ608917 & & \\
\hline A. flavicollis & Spain & Catalonia & $\mathrm{Sp}$ & Fla.Sp & AM408286 & AM409062 & AM409078 \\
\hline & & & $\mathrm{Sp}$ & Fla.Sp & AM408287 & & \\
\hline & France & Loiret & $\mathrm{Fr}$ & Fla.Fr & AM408288 & & \\
\hline & Turkey & Ayder & Tu1 & Fla.Tu1 & AJ971219 & & \\
\hline & Poland & Lublin & Po & Fla.Po & AM408290 & & \\
\hline & Italy & Calabria & It2 & Fla.It2 & AM408291 & & \\
\hline & & Liguria & It1 & Fla.It1 & AM408292 & & \\
\hline & & & It1 & Fla.It1 & AM408293 & & \\
\hline & & & It1 & Fla.It1 & AM408294 & AM409071 & AM409087 \\
\hline & & & It1 & Fla.It1 & AM408295 & AM409072 & AM409088 \\
\hline & Greece & Thessaly & Gr4 & Fla.Gr4 & AM408296 & AM409067 & AM409083 \\
\hline & Slovakia & Kosicky Kraj & $\mathrm{Sa}$ & Fla.Sa & AM408297 & & \\
\hline & & & $\mathrm{Sa}$ & Fla.Sa & AM408298 & & \\
\hline & & & $\mathrm{Sa}$ & Fla.Sa & AM408299 & & \\
\hline & & & $\mathrm{Sa}$ & Fla.Sa & AM408300 & & \\
\hline & Slovenia & Vipava & S11 & Fla.S11 & AJ971193 & & \\
\hline & & & Sl1 & Fla.Sl1 & AJ971194 & & \\
\hline & & Pohorje & $\mathrm{S} 12$ & Fla.S12 & AJ971195 & & \\
\hline & & & $\mathrm{S} 12$ & Fla.S12 & AJ971196 & & \\
\hline & Romania & Baile Herculane & Ro & Fla.Ro & AM408301 & AM409070 & AM409086 \\
\hline & Czech Republic & Unknown & $\mathrm{Cz}$ & Fla.Cz & AM408302 & & \\
\hline A. uralensis & Russia & Novosibirsk & $\mathrm{Ru}$ & Ura.Ru & AM408303 & & \\
\hline & Slovakia & Kosicky Kraj & $\mathrm{Sa}$ & Ura.Sa & AM408304 & AM409068 & AM409084 \\
\hline & & & $\mathrm{Sa}$ & Ura.Sa & AM408305 & AM409069 & AM409085 \\
\hline & & & $\mathrm{Sa}$ & Ura.Sa & AM408306 & & \\
\hline A. agrarius & Poland & Lublin & Po & Agr.Po & AM408307 & & \\
\hline & & & Po & Agr.Po & AM408308 & & \\
\hline & & & Po & Agr.Po & AM408309 & & \\
\hline
\end{tabular}


Table 1 (continued)

\begin{tabular}{|c|c|c|c|c|c|c|c|}
\hline \multirow[t]{2}{*}{ Host } & \multirow[t]{2}{*}{ Country } & \multirow[t]{2}{*}{ Region } & \multirow[t]{2}{*}{ Geo. Code } & \multirow[t]{2}{*}{ Samp. Code } & \multicolumn{3}{|c|}{ EMBL Accession Numbers $^{\mathrm{a}}$} \\
\hline & & & & & cytb & ITS1 & ITS2 \\
\hline & & & $\begin{array}{l}\mathrm{Po} \\
\mathrm{Po} \\
\mathrm{Po}\end{array}$ & $\begin{array}{l}\text { Agr.Po } \\
\text { Agr.Po } \\
\text { Agr.Po }\end{array}$ & $\begin{array}{l}\text { AM408310 } \\
\text { AM408311 } \\
\text { AM408312 }\end{array}$ & & \\
\hline A. mystacinus & $\begin{array}{l}\text { Turkey } \\
\text { Greece }\end{array}$ & $\begin{array}{l}\text { Ayder } \\
\text { Ortan } \\
\text { Corinthe }\end{array}$ & $\begin{array}{l}\text { Tu1 } \\
\text { Tu1 } \\
\text { Tu3 } \\
\text { Tu3 } \\
\text { Gr3 } \\
\text { Gr3 }\end{array}$ & $\begin{array}{l}\text { Mys.Tu1 } \\
\text { Mys.Tu1 } \\
\text { Mys.Tu3 } \\
\text { Mys.Tu3 } \\
\text { Mys.Gr3 } \\
\text { Mys.Gr3 }\end{array}$ & $\begin{array}{l}\text { AJ971220 } \\
\text { AJ971207 } \\
\text { AJ971222 } \\
\text { AJ971221 } \\
\text { AM408313 } \\
\text { AM408314 }\end{array}$ & AM409074 & AM409090 \\
\hline A. alpicola & Austria & Tyrol & $\mathrm{Au}$ & Alp.Au & AM408315 & & \\
\hline Outgroups & $\begin{array}{l}\text { Japan } \\
\text { Syria }\end{array}$ & $\begin{array}{r}\text { H. kuriler } \\
\text { Heligmo }\end{array}$ & $\begin{array}{l}\text { ayashi } \\
p \text {. }\end{array}$ & & $\begin{array}{l}\text { AJ971146 } \\
\text { AM408289 }\end{array}$ & AM409077 & AM409093 \\
\hline
\end{tabular}

\footnotetext{
a Numbers in bold represent new sequences for the present study.
}

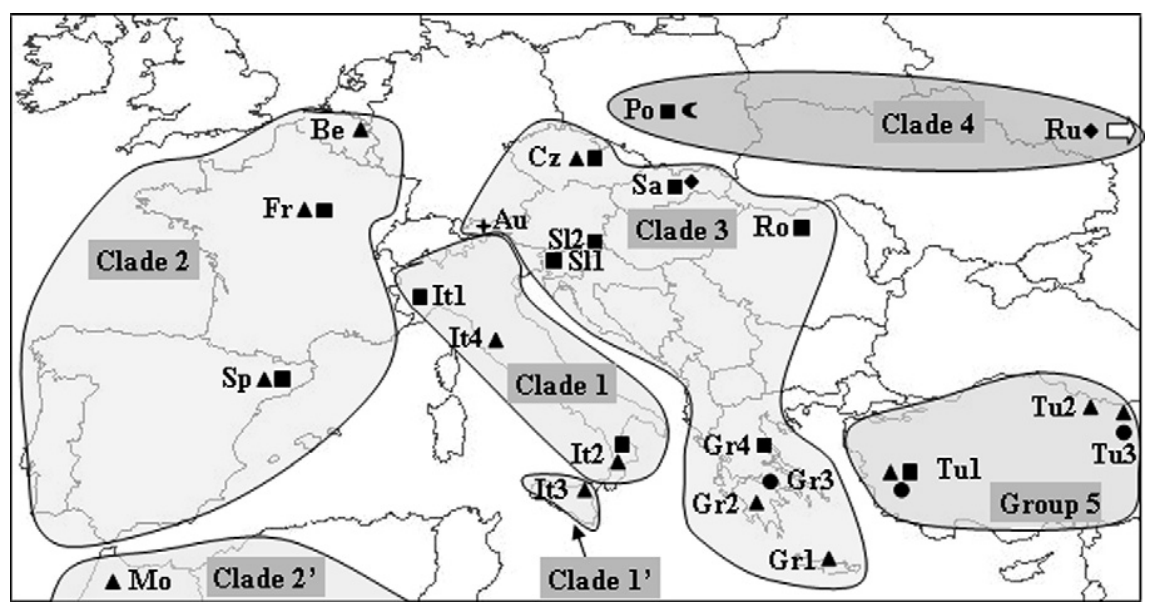

Fig. 2. Geographical distribution of Heligmosomoides samples and the extension of their genetic clades. Host species: triangle: A. sylvaticus; square: A. flavicollis; circle: A. mystacinus; cross: A. alpicola; diamond: A. uralensis; moon: A. agrarius. The geographical codes are as in Table 1.

Phylogenetic reconstructions were performed on each of the $c y t b$ gene and ITS partitions using a Bayesian procedure as implemented by BayesPhylogenies (Pagel and Meade, 2004). Four chains of $1,000,000$ iterations were run and trees were sampled every 10,000 generations to ensure independence of successive trees. The number of generations needed to reach stationnarity in the Markov chain Monte Carlo (MCMC) algorithm was estimated by visual inspection of the plot of the ML score at each sampling point. The trees of the'burn-in' for each run were excluded from the tree set, and the remaining trees from each run were combined to form the full sample of trees assumed to be representative of the posterior probability distribution. An attractive feature of this new MCMC approach is that the performance of increasingly complex substitution models involving several rate matrices can be evaluated without a priori partitioning of the data. We contrasted the performance of increasingly complex models simultaneously employing one to three general time-reversible (GTR) rate matrices, and with or without gamma distributions (with four rate multipliers) to model withinmatrix rate heterogeneity. The appropriate model was determined by plotting the log-likelihood values against the standard deviations of the rate matrix parameters. We looked for a cut-off point that corresponds to a slowing in the improvement to the overall log-likelihood and a sharp increase in the error associated with the estimation of the model parameters. In order to test competing hypotheses of host versus geographic differentiation in the parasites, the ITS and cytb data matrices were also re-analyzed under the constraint that the clades of the parasite conform to either a host or to a geographic pattern. For that purpose, the Bayesian analysis was re-run under the constraint that the parasites from the same host [e.g., for the ITS data set: ((Syl.Sp, Syl.Mo, Syl.Mo, Syl.It2, Syl.Gr1, Syl.Tu2, Syl.Tu2) (Fla.Sp, Fla.It1, Fla.It1, 
Fla.Ro, Fla.Gr4) (Ura.Sa, Ura.Sa) (Mys.Tu1))] or from the same geographic region [e.g., for the ITS data set: ((Fla.Sp, Syl.Sp) (Syl.Mo, Syl.Mo) (Fla.It1, Fla.It1, Syl.It2) (Syl.Gr1, Ura.Sa, Fla.Ro, Fla.Gr4, Ura.Sa) (Syl.Tu2, Syl.Tu2, Mys.Tu1))] are monophyletic. The significance of the difference in average log-likelihood in the constrained and unconstrained runs, respectively, was assessed by computing the Bayes factors. The Bayes factors represent a summary of the evidence provided by the data in favor of a certain model (Kass and Raftery, 1995). A model provides a significantly better representation of the data than another model if twice the difference of the log marginal likelihood returned by the respective models is
$>5$ (Kass and Raftery, 1995; Raftery, 1996; Pagel and Meade, 2004). The marginal likelihoods of the different models are well approximated by the harmonic mean of the likelihoods when the Markov chain is allowed to run for a very large number (millions) of iterations (Kass and Raftery, 1995; Raftery, 1996).

\subsection{Co-speciation analyses}

TreeMap 1.0b (Page, 1994) was used to test for significant co-differentiation between the parasite and its host. For that purpose, the 50\% majority-rule consensus tree of the trees sampled from the posterior probability distribu-

Table 2

Occurrence of the different Apodemus species in the Western Palearctic region, gathered from the field missions realized between 1963 and 2004

\begin{tabular}{|c|c|c|c|c|c|c|c|c|c|}
\hline \multirow[t]{2}{*}{ Country } & \multirow[t]{2}{*}{ Year } & \multicolumn{7}{|c|}{ Number of trapped individuals } & \multirow[t]{2}{*}{ References } \\
\hline & & Apodemus & $s y l^{\mathrm{a}}$ & $f l a^{\mathrm{b}}$ & $m y s^{\mathrm{c}}$ & $a g r^{\mathrm{d}}$ & $u r a^{\mathrm{e}}$ & $a^{a l p^{\mathrm{f}}}$ & \\
\hline \multicolumn{10}{|c|}{ South Eastern Europe } \\
\hline \multirow[t]{6}{*}{ Czech } & 2001 & 69 & 16 & 49 & 0 & 4 & 0 & 0 & Vostal and Zakovska (2003) \\
\hline & 2002 & 67 & 1 & 57 & 0 & 9 & 0 & 0 & Vostal and Zakovska (2003) \\
\hline & 1992 & 11 & 0 & 11 & 0 & 0 & 0 & 0 & Zeman and Daniel (1999) \\
\hline & 1992 & 161 & 17 & 144 & 0 & 0 & 0 & 0 & Zeman and Januska (1999) \\
\hline & 1963-1968 & 537 & 115 & 422 & 0 & 0 & 0 & 0 & Prokopic (1972) \\
\hline & 1999-2001 & 301 & 78 & 223 & 0 & 0 & 0 & 0 & Barciová and Macholán (2006) \\
\hline Greece & 2003 & 13 & 0 & 9 & 4 & 0 & 0 & 0 & This study (Nieberding and Deffontaine sampling) \\
\hline \multirow[t]{4}{*}{ Slovakia } & 1997-1998 & 361 & 0 & 55 & 0 & 306 & 0 & 0 & Sibold et al. (2001) \\
\hline & 1983-1997 & 7111 & 82 & 3598 & 0 & 2538 & 893 & 0 & Stanko et al. (2002) \\
\hline & 1985-1992 & 322 & 21 & 183 & 0 & 109 & 9 & 0 & Stefancikova et al. (1994) \\
\hline & 2002 & 22 & 0 & 11 & 0 & 0 & 11 & 0 & This study (Morand and Feliu 's teams sampling) \\
\hline Serbia & 1997-1999 & 2032 & 0 & 1524 & 0 & 508 & 0 & 0 & Vukicevic-Radic et al. (2006) \\
\hline Slovenia & 2004 & 16 & 1 & 13 & 0 & 2 & 0 & 0 & This study (Nieberding and Libois sampling) \\
\hline Total & & 11023 & 331 & 6299 & 4 & 3476 & 913 & 0 & \\
\hline \multicolumn{10}{|c|}{ South Western Europe } \\
\hline \multirow[t]{5}{*}{ Italy } & 2001 & 37 & 33 & 4 & 0 & 0 & 0 & 0 & This study (Morand and Feliu's teams sampling) \\
\hline & 2002 & & 2 & 9 & 0 & & 0 & 0 & This study (Nieberding and Michaux sampling) \\
\hline & 1992-1993 & 696 & 441 & 255 & 0 & 0 & 0 & 0 & Agnelli and Bellini (1997) \\
\hline & 1991-1992 & & Dominant & 0 & 0 & 0 & 0 & 0 & Canova (1992) \\
\hline & 1984-2001 & 891 & 697 & 194 & 0 & 0 & 0 & 0 & Milazzo (2001) \\
\hline Belgium & 2002 & 16 & 16 & 0 & 0 & 0 & 0 & 0 & This study (Nieberding sampling) \\
\hline \multirow[t]{5}{*}{ France } & 1998-1999 & & Dominant & 0 & 0 & 0 & 0 & 0 & de la Pena et al. (2003) \\
\hline & 1995 & 839 & 839 & 0 & 0 & 0 & 0 & 0 & Butet et al. (2006) \\
\hline & 2004-2006 & 195 & 60 & 135 & 0 & 0 & 0 & 0 & J. Deter, N. Charbonnel, JF Cosson, unpubl. data \\
\hline & 2002 & 24 & 24 & 0 & 0 & 0 & 0 & 0 & This study (Nieberding and Goüy sampling) \\
\hline & 2002 & 34 & 34 & 0 & 0 & 0 & 0 & 0 & This study (Morand and Feliu's teams sampling) \\
\hline \multirow[t]{4}{*}{ Spain } & 2001-2002 & 63 & 43 & 20 & 0 & 0 & 0 & 0 & Ribas et al. (2004) \\
\hline & 2001-2002 & 164 & 150 & 14 & 0 & 0 & 0 & 0 & Sainz-Elipe et al. (2004) \\
\hline & 1996 & 29 & 23 & 6 & 0 & 0 & 0 & 0 & Arrizabalaga et al. (1999) \\
\hline & Not known & 59 & 56 & 3 & 0 & 0 & 0 & 0 & Fernandes et al. (1991) \\
\hline \multirow[t]{2}{*}{ Switzerland } & 1993-1994 & 86 & 60 & 26 & 0 & 0 & 0 & 0 & Humair et al. (1995) \\
\hline & 1995-1998 & 41 & 8 & 13 & 0 & 0 & 0 & 20 & Asakawa et al. (1999) \\
\hline Austria & 2002 & 11 & 0 & 0 & 0 & 0 & 0 & 11 & This study (Libois sampling) \\
\hline Total & & 3185 & 2486 & 679 & 0 & 0 & 0 & 31 & \\
\hline
\end{tabular}

Northern Europe (including Poland) and the Middle East were not included in the present survey due to the lack of available information. Differences in species abundance was highly significant in each region (proportion tests, $p<2.2 \times 10^{-16}$ ).
a . sylvaticus.
b A. flavicollis.
c A. mystacinus.
d A. agrarius.
e A. uralensis
f A. alpicola. 
tion resulting from the analysis of the cyt $b$ gene in Heligmosomoides was confronted to the Apodemus phylogeny. The latter was inferred from $c y t b$ gene sequences for $A$. sylvaticus, A. flavicollis and A. mystacinus (the three relevant potential host species, see results) that were re-analyzed here in a Bayesian context for consistency (data not shown, available from the authors on request). Because TREeMAP requires strictly dichotomous trees, polytomies in the Heligmosomoides and Apodemus consensus trees were randomly broken by branches of infinitesimal length.

TreeMaP computes the fit between the two phylogenies, incorporating a differential cost of the four types of potential events occurring in a host-parasite association: co-differentiation, duplication, sorting and host switching (Page, 2003). Co-speciation tests were performed between partial $c y t b$ gene datasets of the parasite and the $c y t b$ gene data sets of the hosts sampled in the corresponding geographic locations (see Section 3 for details).

TREeMAP includes a testing procedure, by generating random parasite trees and estimating the distribution of the random number of co-speciation events in the hostparasite associations. We generated 10,000 random parasite trees for each host-parasite comparison and the number of co-differentiation events between the 10,000 random parasite trees and the corresponding host tree was calculated. This gives the theoretical distribution of the number of co-differentiation events observed by chance in case the host and the parasite had an independent history. This theoretical distribution was used to estimate whether the number of co-differentiation events observed between the host tree and twenty-one parasite trees sampled within the four hundred trees selected by the Bayesian analysis was significantly higher than by chance alone. Significance was reached if the number of co-differentiation events between a real parasite tree and the host tree was higher than the number of co-differentiation events expected in the $95 \%$ confidence interval of the theoretical random distribution. The $95 \%$ confidence interval is defined by the mean number of co-differentiation events and two standard deviations of the theoretical distribution. This assessed whether co-speciation in each host-parasite comparison was significantly higher than by chance alone.

\subsection{Estimation of divergence time of parasite lineages}

It is generally problematic to calibrate the absolute rate of evolution of invertebrates such as nematode parasites, because of the lack of fossil records. Yet, we showed previously, using orthologous DNA coding regions ( $c y t b$ gene) in both species, that the genetic clades of $H$. polygyrus and A. sylvaticus of south western Europe differentiated simultaneously in the past (Nieberding et al., 2004). This allowed us to use the absolute divergence rate between the $c y t b$ lineages in A. sylvaticus, which was calculated on the basis of rodent paleontological data (Michaux et al., 2003), to estimate the rate of genetic divergence in the corresponding parasite $c y t b$ lineages (Nieberding et al., 2004). The level of genetic divergence for $H$. polygyrus cyt $b$ gene was estimated to $3.5-3.7 \% \mathrm{~K}_{2} \mathrm{P}$ (Kimura' s two parameter distance estimator) distance per million years. Genetic divergence was estimated in $\mathrm{K}_{2} \mathrm{P}$ distances to allow comparison with most of the published phylogeographic studies (e.g., see Avise et al., 1998), and was corrected for ancestral mtDNA polymorphism (Edwards and Beerli, 2000). This estimation was used in this study to infer the isolation epoch of the new parasite genetic lineages (Polish, Turkish and Moroccan).

\section{Results}

\subsection{Phylogenetic reconstructions of Heligmosomoides}

\subsubsection{Phylogenetic relationships of cyt $b$ sequences}

A total of fifty-two haplotypes were identified among the seventy Heligmosomoides cyt $b$ sequences (EMBL Accession Nos. AM408285-AM408314 for the new sequences; Table 1). The matrix provided $690 \mathrm{bp}$, of which sixty sites were variable. The analysis of the matrix under increasingly complex substitution models simultaneously employing one to three rate matrices, and with or without gamma distributions to model within-matrix rate heterogeneity, suggested that a single-matrix model with a gamma distribution was best appropriate to the data. From that level of complexity indeed, adding more rate matrices did not improve the overall log-likelihood but resulted in a dramatic increase in the standard deviation of the rate parameters (data not shown). The average and standard deviation of the nucleotide proportions, of the rate parameters, and of the shape parameter of the gamma distribution from the posterior probability distribution are provided (additional Table 1 available online).

In the $50 \%$ majority-rule consensus of the 394 trees (average $\ln L=-4031.02$ ) sampled after convergence of the four MCMC's implementing a GTR $+\Gamma$ substitution model (Fig. 3), all besides the Turkish Heligmosomoides sequences fell into the strongly differentiated genetic lineages (Fig. 2). The Italian (clade 1), Sicilian (clade 1'), south-western European (clade 2), Moroccan (clade 2'), the Balkan (clade 3) and the eastern European (Polish and Russian, clade 4) populations form strongly supported lineages (posterior probabilities, noted hereafter p.p., between 0.78 and 1.00). The Turkish populations do not form a clade, but remain clearly differentiated from all other populations (group 5). These clades are also differentiated from the northern European lineage-previously identified in Ireland and Denmark - which was not included in the present study (data not shown; Nieberding, 2005a; Nieberding et al., 2005b).

Constraining the MCMC to sample only trees fitting with the geographic constraint did not result in a significant decrease in log-likelihood (Bayes factor, B. F. = 4.5). By contrast, imposing a structure, wherein parasites from the same host are monophyletic, resulted in a substantial decrease in log-likelihood (B. F. =707). Thus, Heligmo- 


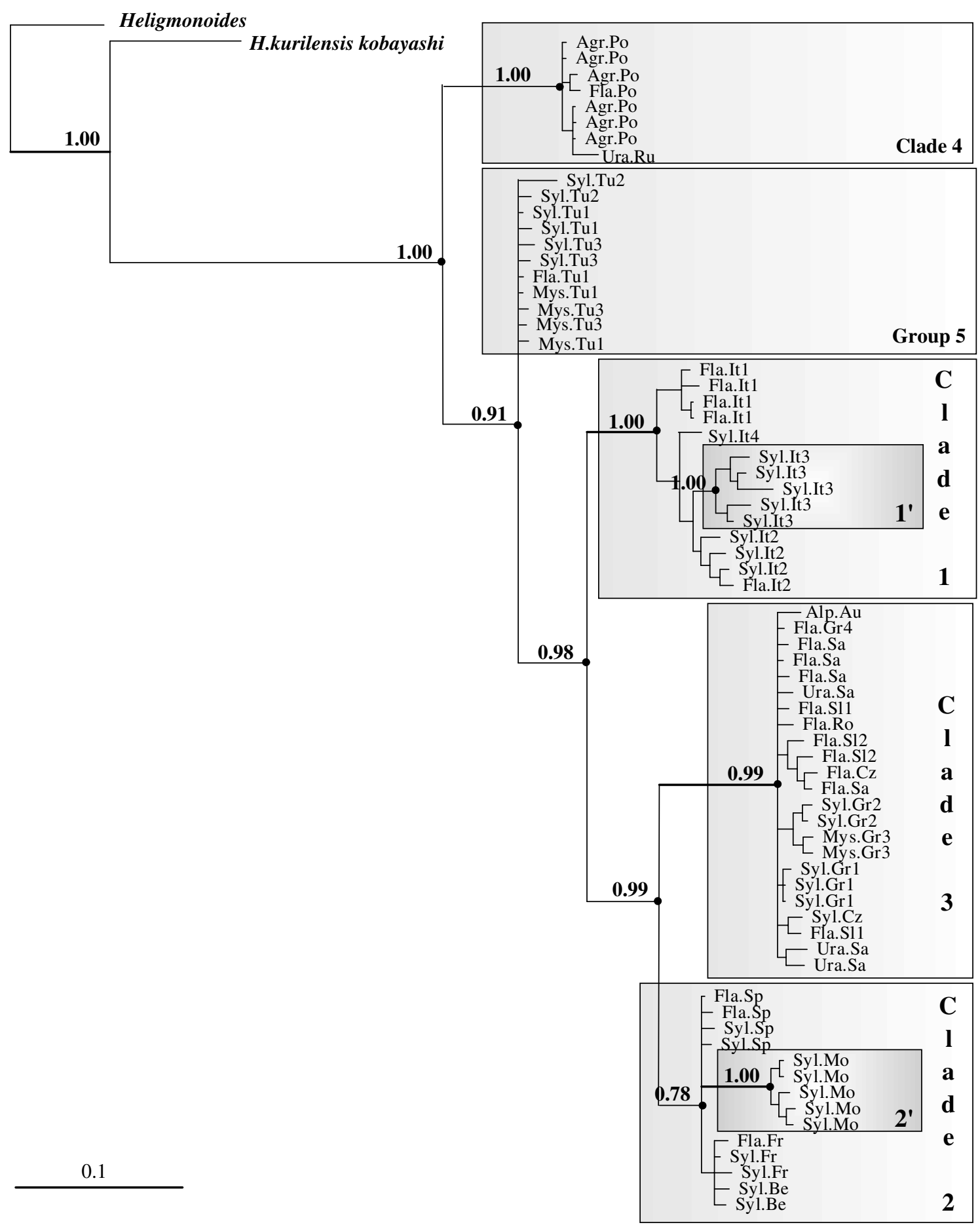

Fig. 3. Fifty percent majority-rule consensus with branch lengths averaged over the 394 trees sampled during the Bayesian analysis of seventy Heligmosomoides mitochondrial cyt $b$ gene sequences employing four chains and a GTR $+\Gamma$ substitution matrix. Each accession is represented by its geographical origin and host species name (see Table 1 and Fig. 2). Numbers on branches indicate posterior probabilities $>0.75$. Bold lines represent nodes that were also supported by posterior probabilities $>0.75$ in the phylogenetic reconstructions using the ITS data (see Fig. 4).

somoides lineages are not specific to the wood mouse $A$. sylvaticus but can be found in the six most common species of Apodemus rodents, namely A. sylvaticus, A. flavicollis, A. mystacinus, A. alpicola, A. uralensis and A. agrarius. Moreover, the phylogenetic reconstructions also reveal that Heligmosomoides individuals in the various Apodemus hosts did not differentiate according to the host species that they par- asitize. Rather, Heligmosomoides lineages differentiated in allopatric geographic areas.

\subsubsection{Phylogenetic relationships of ITS sequences}

ITS1 and ITS2 sequences could be obtained for a few individuals belonging to the clades 1, 2, 2', 3 and for three Turkish individuals (EMBL Accession Nos. AM409062- 
AM409093; Table 1). The matrix provided 988 bp of which thirty sites were variable. The analysis of the matrix under increasingly complex substitution models showed that a single-matrix model was best appropriate to the data (data not shown). The average and standard deviation of the nucleotide proportions and of the rate parameters from the posterior probability distribution are provided (additional Table 1 available online). In the 50\% majority-rule consensus of the 396 trees (average $\ln L=-2145.50$ ) sampled after convergence of the four MCMC's implementing a GTR $+\Gamma$ substitution model (Fig. 4), all Heligmosomoides individuals form a monophyletic group (p.p. of 1.00); the existence of the clades $1,2^{\prime}$ and 3 (p.p. of 1.00, 1.00 and 0.86 , respectively) was also confirmed. In contrast to the $c y t b$ phylogeny, the south western populations (clade 2 in the $c y t b$ phylogenetic tree) do not form a monophyletic lineage. Moreover, the Moroccan subclade is not directly linked to the south western individuals. This could be due to the low level of polymorphism of ITS sequences, which, combined to the small number of sequenced individuals, might limit the resolution of the phylogenetic relationships among the samples. Finally, the Turkish individuals form a monophyletic lineage (clade 5; p.p. of 0.82) distinct from all other populations.

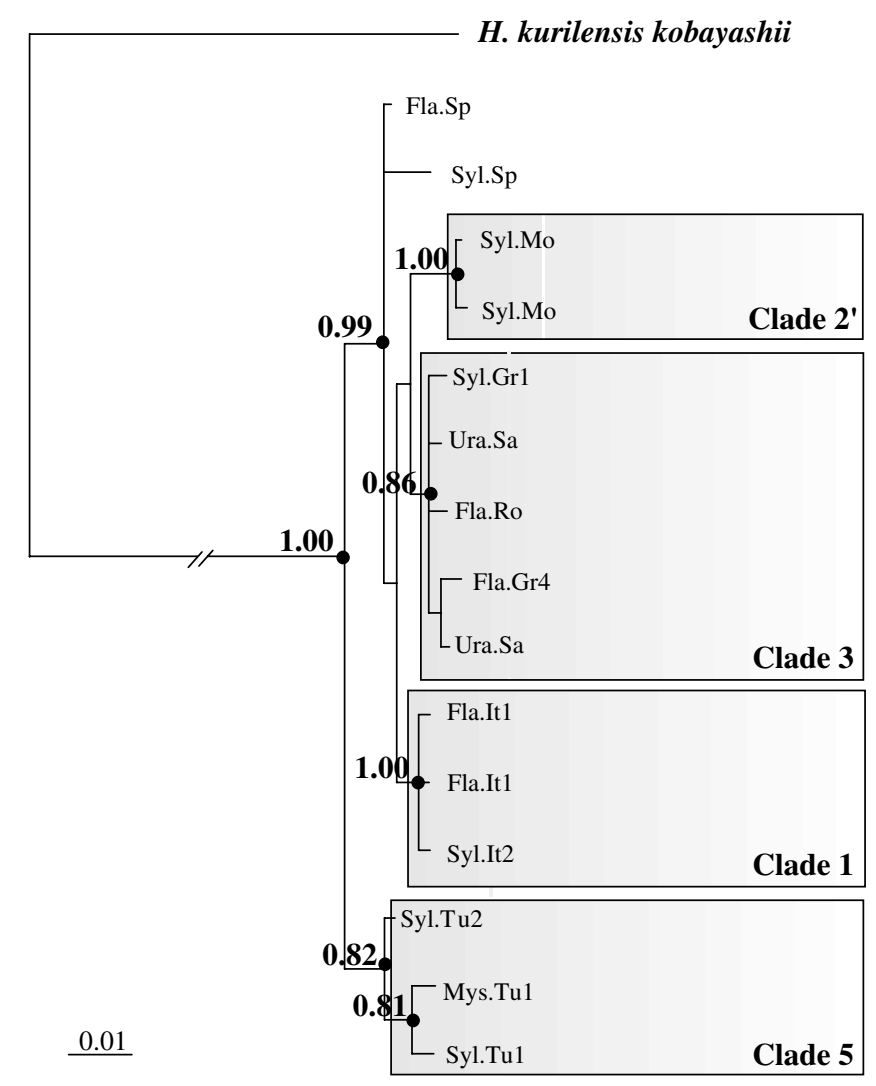

Fig. 4. Fifty percent majority-rule consensus with branch lengths averaged over the 396 trees sampled during the Bayesian analysis of fifteen Heligmosomoides ITS sequences employing four chains and a GTR $+\Gamma$ substitution matrix. Each accession is represented by its geographical origin and host species name (see Table 1 and Fig. 2). Numbers on branches indicate posterior probabilities $>0.75$.
Both the geographic and host species constraints resulted in significantly lower log-likelihoods. However, while the geographic constraint resulted in a small decrease (B. F. = 13), the species host constraint induced a much bigger decrease in log-likelihood (B. F. =94). This confirms the results highlighted by the cyt $b$ data: parasites group more closely together according to their geographic origin than according to the host species they parasitize.

\subsection{Co-differentiation analyses between Heligmosomoides lineages and Apodemus hosts}

While strict co-speciation between Heligmosomoides parasites and Apodemus hosts is not corroborated by the present data, a closer analysis of the geographic subdivision of Heligmosomoides lineages highlights some striking similarities with the distribution range of the lineages of some Apodemus hosts. Therefore, we next examined whether the parasite lineages showed a level of co-differentiation with either A. flavicollis or A. mystacinus host species in Eastern Europe and in the Middle East (see Introduction) which was comparable to the level of co-differentiation with $A$. sylvaticus in Western Europe.

First, the level of co-differentiation between Heligmosomoides and $A$. sylvaticus in Western Europe, including here the North African populations, was used as a control to interpret the level of co-differentiation observed between Heligmosomoides lineages and A. flavicollis or A. mystacinus in Eastern Europe and in the Middle East. A subset of the cyt $b$ gene sequences where hosts and parasites were both sampled was used for phylogenetic reconstructions (Table 3A). The parasite sequences were used here without consideration to the sampled host species, given that it was the hypothesis of geographic differentiation that was tested. The parasite consensus tree, as well as twenty randomly chosen parasite trees sampled from the Bayesian analyses, were generated. The topologies of the host and the twenty-one parasite trees were similar to the phylogenetic trees obtained with the complete datasets (Fig. 5A, left). Using TREEMAP, the number of co-differentiation events between each of the 21 parasite trees and the tree of $A$. sylvaticus was calculated. The comparisons of the host and the parasite topologies revealed 15-19 co-differentiation events, depending on which parasite tree was considered in the successive comparisons (Fig. 5C, left). The significance of this result was estimated by generating 10,000 random parasite trees and recalculating the number of co-differentiation events. The results demonstrated that the observed number of co-differentiation events in all of the 21 real parasite trees was significantly higher than what was observed in the 10,000 random associations (Fig. 5B and C, left).

Similarly, we assessed the level of co-differentiation between A. flavicollis and Heligmosomoides in Eastern Europe and in the Middle East (Table 3B; Fig. 5A, middle). The comparison of the host and the parasite topologies revealed 11-18 co-differentiation events, depending on which of the 21 parasite trees was considered in the succes- 
Table 3

Cyt $b$ sequences used from Heligmosomoides and (A) A. sylvaticus, (B) A. flavicollis and (C) A. mystacinus in the three consecutive TreeMap analyses

\begin{tabular}{|c|c|c|c|c|}
\hline \multirow[t]{2}{*}{ Country } & \multirow[t]{2}{*}{ Region } & \multirow[t]{2}{*}{ Parasite codes } & \multicolumn{2}{|l|}{ Host } \\
\hline & & & Codes & EMBL \\
\hline \multicolumn{5}{|c|}{ A. Heligmosomoides and A. sylvaticus associations (West) } \\
\hline \multirow[t]{4}{*}{ Spain } & Catalonia & Syl.Sp & $\mathrm{Sp}$ & AJ511912 \\
\hline & & Syl.Sp & $\mathrm{Sp}$ & AJ511913 \\
\hline & & Fla.Sp & $\mathrm{Sp}$ & AJ511880 \\
\hline & & Fla.Sp & $\mathrm{Sp}$ & AJ511914 \\
\hline \multirow[t]{3}{*}{ France } & Loiret & Syl.Fr & $\mathrm{Fr}$ & AJ511898 \\
\hline & & Syl.Fr & $\mathrm{Fr}$ & AJ511899 \\
\hline & & Fla.Fr & $\mathrm{Fr}$ & AJ511901 \\
\hline \multirow[t]{2}{*}{ Belgium } & Liège & Syl.Be & $\mathrm{Be}$ & AJ511903 \\
\hline & & Syl.Be & $\mathrm{Be}$ & AJ511879 \\
\hline \multirow[t]{5}{*}{ Morocco } & Haut Atlas & Syl.Mo & Mo & AJ511921 \\
\hline & & Syl.Mo & Mo & AJ511920 \\
\hline & & Syl.Mo & Mo & AJ511919 \\
\hline & & Syl.Mo & Mo & AJ511922 \\
\hline & & Syl.Mo & $\operatorname{Tn}^{\mathrm{a}}$ & AJ511917 \\
\hline \multirow[t]{13}{*}{ Italy } & Calabria & Syl.It2 & It 2 & AJ511948 \\
\hline & & Syl.It2 & It 2 & AJ511949 \\
\hline & & Syl.It2 & It 2 & AJ511950 \\
\hline & & Fla.It2 & It 2 & AJ511951 \\
\hline & Tuscany & Syl.It4 & It4 & AJ511929 \\
\hline & Liguria & Fla.It1 & $\mathrm{It} 5^{\mathrm{b}}$ & AJ511925 \\
\hline & & Fla.It1 & $\mathrm{It} 5^{\mathrm{b}}$ & AJ511926 \\
\hline & & Fla.It1 & $\mathrm{It} 5^{\mathrm{b}}$ & AJ511982 \\
\hline & Sicily & Syl.It3 & It3 & AJ511962 \\
\hline & & Syl.It3 & It3 & AJ511959 \\
\hline & & Syl.It3 & It3 & AJ511963 \\
\hline & & Syl.It3 & It3 & AJ511960 \\
\hline & & Syl.It3 & It3 & AJ511961 \\
\hline
\end{tabular}

B. Heligmosomoides and A. flavicollis associations (East)

\begin{tabular}{|c|c|c|c|c|}
\hline \multirow[t]{11}{*}{ Turkey } & \multirow[t]{5}{*}{ Ayder } & Syl.Tu1 & Tu1 & AJ605681 \\
\hline & & Syl.Tu1 & Tul & AJ605680 \\
\hline & & Fla.Tul & Tul & AJ605668 \\
\hline & & Mys.Tu1 & Tul & AJ605667 \\
\hline & & Mys.Tu1 & Tul & AJ605670 \\
\hline & \multirow[t]{2}{*}{ Bozdag } & Syl.Tu2 & $\mathrm{Tu} 2$ & AJ605677 \\
\hline & & Syl.Tu2 & $\mathrm{Tu} 2$ & AJ605679 \\
\hline & \multirow[t]{4}{*}{ Ortan } & Syl.Tu3 & Tu3 & AJ605685 \\
\hline & & Syl.Tu3 & Tu3 & AJ605684 \\
\hline & & Mys.Tu3 & Tu3 & AJ605669 \\
\hline & & Mys.Tu3 & Tu4 & AJ605682 \\
\hline \multirow[t]{2}{*}{ Czeck } & \multirow[t]{2}{*}{ Unknown } & Syl.Cz & $\mathrm{Cz}$ & AJ605607 \\
\hline & & Fla.Cz & $\mathrm{Cz}$ & AJ605609 \\
\hline \multirow[t]{8}{*}{ Greece } & \multirow[t]{3}{*}{ Crete } & Syl.Gr1 & $\mathrm{Gr} 2^{\mathrm{c}}$ & AJ605624 \\
\hline & & Syl.Gr1 & $\mathrm{Gr} 2^{\mathrm{c}}$ & AJ605625 \\
\hline & & Syl.Gr1 & $\mathrm{Gr} 2^{\mathrm{c}}$ & AJ605628 \\
\hline & \multirow[t]{2}{*}{ Peloponnisos } & Syl.Gr2 & Gr2 & AJ605632 \\
\hline & & Syl.Gr2 & Gr2 & AJ 605627 \\
\hline & \multirow[t]{2}{*}{ Corinthe } & Mys.Gr3 & Gr3 & AJ605644 \\
\hline & & Mys.Gr3 & Gr3 & AJ605626 \\
\hline & Thessalia & Fla.Gr4 & $\mathrm{Gr} 3^{\mathrm{d}}$ & AJ605617 \\
\hline \multirow[t]{3}{*}{ Slovaquia } & \multirow[t]{3}{*}{ Kosicky Kraj } & Fla.Sa & $\mathrm{Cz}^{\mathrm{e}}$ & AJ605605 \\
\hline & & Fla.Sa & $\mathrm{Cz}^{\mathrm{e}}$ & AJ605606 \\
\hline & & Ura.Sa & $\mathrm{Cz}^{\mathrm{e}}$ & AJ605608 \\
\hline \multirow[t]{3}{*}{ Slovenia } & \multirow[t]{2}{*}{ Vipava } & Fla.S11 & $\mathrm{S} 1$ & AJ605656 \\
\hline & & Fla.S12 & S1 & AJ 605655 \\
\hline & Pohorje & Fla.S12 & $\mathrm{S} 1$ & AJ605657 \\
\hline Romania & Baile Herculane & Fla.Ro & Ro & AJ605646 \\
\hline
\end{tabular}

Table 3 (continued)

\begin{tabular}{|c|c|c|c|c|}
\hline \multirow[t]{2}{*}{ Country } & \multirow[t]{2}{*}{ Region } & \multirow[t]{2}{*}{ Parasite codes } & \multicolumn{2}{|l|}{ Host } \\
\hline & & & Codes & EMBL \\
\hline \multicolumn{5}{|c|}{ C. Heligmosomoides and A. mystacinus associations (East) } \\
\hline \multirow[t]{7}{*}{ Turkey } & Ayder & Mys .Tu1 & $\mathrm{Tu} 5^{\mathrm{f}}$ & AJ748240 \\
\hline & Bozdag & Syl.Tu2 & $\mathrm{Tu} 5^{\mathrm{f}}$ & AJ748226 \\
\hline & & Syl.Tu2 & $\mathrm{Tu} 5^{\mathrm{f}}$ & AJ748225 \\
\hline & Ortan & Syl.Tu3 & $\mathrm{Sy}^{\mathrm{g}}$ & AJ748236 \\
\hline & & Syl.Tu3 & $\mathrm{Sy}^{\mathrm{g}}$ & AJ748237 \\
\hline & & Mys.Tu3 & $\mathrm{Sy}^{\mathrm{g}}$ & AJ748238 \\
\hline & Sulema road & Mys.Tu3 & $\mathrm{Tu} 5^{\mathrm{f}}$ & AJ748239 \\
\hline \multirow[t]{8}{*}{ Greece } & Corinthe & Mys.Gr3 & $\mathrm{Gr}^{\mathrm{d}}$ & AJ748234 \\
\hline & & Mys.Gr3 & $\mathrm{Gr} 2^{\mathrm{d}}$ & AJ748230 \\
\hline & Crete & Syl.Gr1 & Gr1 & AJ748231 \\
\hline & & Syl.Gr1 & Gr1 & AJ748235 \\
\hline & & Syl.Gr1 & Gr1 & AJ748232 \\
\hline & Peloponnese & Syl.Gr2 & Gr2 & AJ748228 \\
\hline & & Syl.Gr2 & Gr2 & AJ748229 \\
\hline & Thessaly & Fla.Gr4 & $\mathrm{Gr}^{\mathrm{d}}$ & AJ748233 \\
\hline Slovenia & Pohorje & Fla.S12 & $\mathrm{Bu}^{\mathrm{h}}$ & AJ748241 \\
\hline Romania & Baile Herculane & Fla.Ro & $\mathrm{Bu}^{\mathrm{h}}$ & AJ748227 \\
\hline
\end{tabular}

When the Apodemus host sequences and parasite sequences were not available from the same location, we used instead sequences from close regions which belonged to the same genetic clade, as known from the previously published Apodemus phylogeographies (see Michaux et al., 2003, 2004, 2005a). Changes are the followings:

${ }^{a}$ A. sylvaticus sequence comes from Tunisia (Tn).

b A. sylvaticus sequences were sampled in the Abruzzi in the centre of Italy (It5)

c A. flavicollis is absent from Crete. Individuals from the nearby Peloponnese, which colonised Crete (unpublished data), were used instead.

d A. flavicollis and A. mystacinus sequences from different locations in Greece were used according to availability.

e A. flavicollis sequences come from the nearby Czech Republic

f A. mystacinus sequences come from Antalya in Turkey (Tu5).

g A. mystacinus sequences come from nearby Syria (Sy).

${ }^{\mathrm{h}}$ A. mystacinus is absent from Romania and from most of Slovenia. Sequences were thus sampled in the nearby Bulgaria $(\mathrm{Bu})$.

sive comparisons. The observed number of co-differentiation events in 11 of the 21 real parasite trees was significantly higher than the ones in the 10,000 random associations (Fig. 5B and C, middle). Finally, the same approach was applied to the comparison between the phylogenetic trees of Heligmosomoides and A. mystacinus in Eastern Europe and in the Middle East (Fig. 5A, right). When the Apodemus host sequences and parasite sequences were not available from the same location, we used instead sequences from close regions which belonged to the same genetic clade (Table 3C). In this case, the comparison of the host and the parasite topologies revealed 4-9 co-differentiation events, and was significantly higher than in the 10,000 random associations in only 7 of the 21 host-parasite comparisons (Fig. 5B and C, right).

To check whether the dissimilarities between host and parasite sampling schemes in the Heligmosomoides-A. mystacinus comparison $(70 \%$ of the host and parasite sequences were not sampled in the very same location, but well in locations belonging to the same genetic clade) were responsible for the lack of co-differentiation, we repeated the cospeciation test between Heligmosomoides and A. sylvaticus 
A SouthWestern Europe

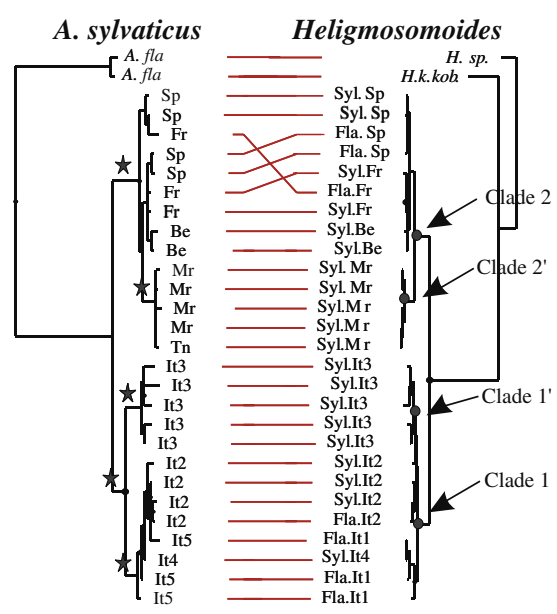

B

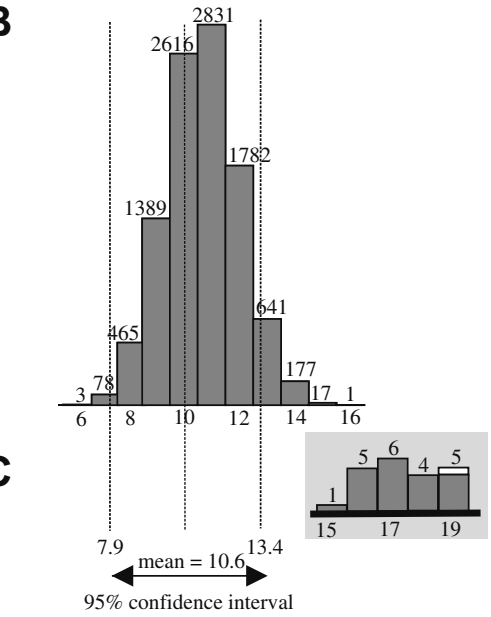

South Eastern Europe
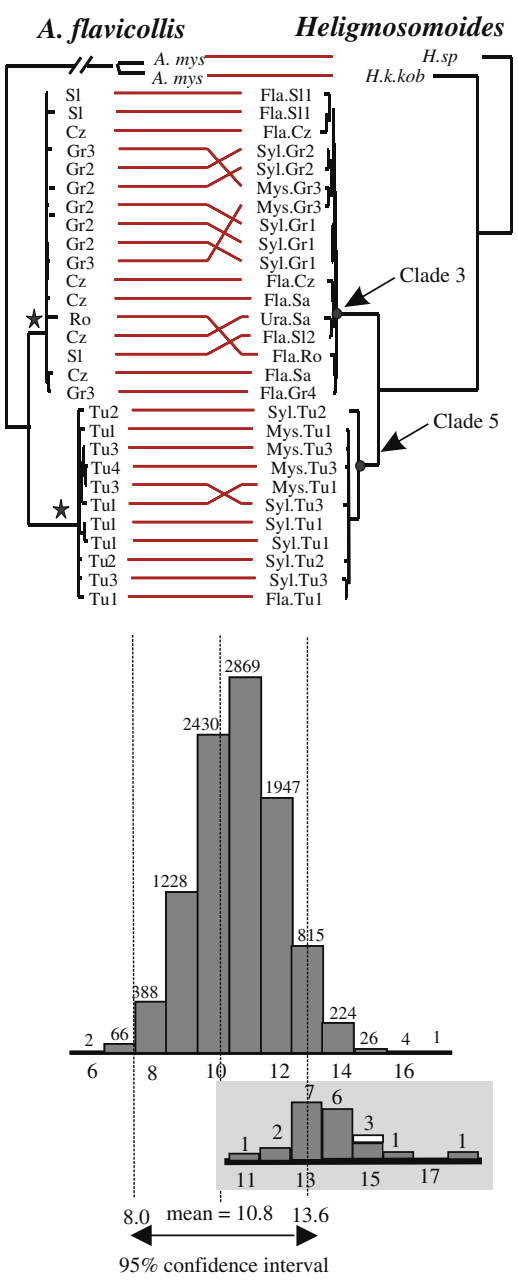

South Eastern Europe
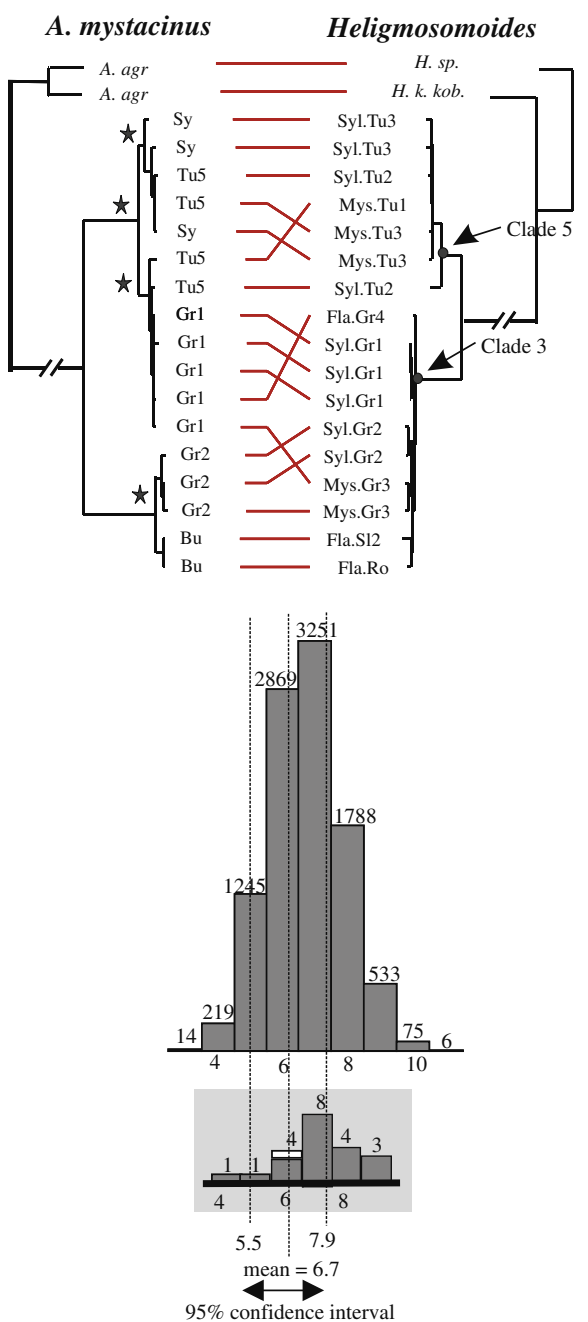

Fig. 5. (A) Pattern of host (A. sylvaticus on the left, A. flavicollis in the middle and A. mystacinus on the right) and parasite associations, using TREEMAP $1.0 \mathrm{~b}$ (Page, 1994). The host tree and the parasite consensus tree were estimated using Bayesian reconstructions with partial data sets (see M\& M). The parasite clades as defined in Figs. 3 and 4 are noted. The host clades that are supported by high bootstrap values when using the whole data sets are mentioned by a star. (B) Histogram showing the distribution of the number of co-differentiation events in associations between the host tree (A. sylvaticus on the left, A. flavicollis in the middle and A. mystacinus on the right) and 10,000 randomly generated parasite trees. The $95 \%$ confidence interval of the number of co-differentiation events in these random associations is indicated. (C) Histogram showing the distribution of the number of co-differentiation events in associations between the host tree (A. sylvaticus on the left, A. flavicollis in the middle and A. mystacinus on the right) and 20 real parasite trees (in grey) as well as the parasite consensus tree (in white).

with a similar design using $70 \%$ of sequences which had been sampled in different locations but the same clade (data not shown). The number of co-differentiation events (19) observed between the consensus host tree and the parasite consensus tree was identical to the one observed in the original A. sylvaticus-Heligmosomoides comparison (see Fig. 5C left). This suggests that the weak host-parasite co-differentiation between Heligmosomoides and A. mystacinus is probably not due to sampling methodology but is biologically meaningful.

\subsection{Estimation of divergence time of parasite lineages}

Based on previous estimations (Nieberding et al., 2004), the rate of $3.5-3.7 \%$ sequence divergence per Myr in $H$. polygyrus cyt $b$ gene was applied in this study to estimate the differentiation time between the Moroccan, Turkish and Polish lineages of Heligmosomoides. The Moroccan lineage was estimated to have differentiated from south Western European populations between 0.54 and 0.57 Million years (Myr) ago. The Turkish lineage differentiated from continental Europe between 1.29 and 1.37 Myr ago, while the Polish lineage differentiated from all other Heligmosomoides lineages between 1.81 and 1.91 Myr ago.

\section{Discussion}

The $c y t b$ and ITS phylogenetic reconstructions revealed that Heligmosomoides genetic lineages segregate according to the geographic origin of the individuals rather than 
according to their host species (Figs. 3 and 4). Yet, the comparison of Heligmosomoides regional phylogenetic trees with A. sylvaticus, A. flavicollis and A. mystacinus phylogenetic trees revealed that co-differentiation was significantly higher than expected by chance between Heligmosomoides and A. sylvaticus in the West and between the parasite and A. flavicollis in the East.

\subsection{Regional co-differentiation between Heligmosomoides and A. sylvaticus in the West}

Three lines of arguments suggest that A. sylvaticus and Heligmosomoides co-differentiated in south Western Europe. First, A. sylvaticus is the most abundant or unique (in North Africa and in Sicily) potential host species for Heligmosomoides in the western part of the parasite continental distribution range. The only other Apodemus species present in part of this area is A. flavicollis (Fig. 1). Yet, the only European refuge for A. flavicollis during the Pleistocene was the Balkan region (Michaux et al., 2004). This is confirmed by paleontological data which show that $A$. flavicollis did not survive up to the last glaciation in western and northern Europe (Aguilar and Michaux, unpubl. data; Cordy, 1984), and attest the presence of A. flavicollis in the Iberian peninsula only from the end of the Lower to the beginning of the Upper Pleistocene (Sese, 1994). Because the genetic differentiation of south western Heligmosomoides lineages predates that time period by an order of magnitude, A. flavicollis cannot be the host on which Iberian and Italian parasites differentiated.

Second, the increasing availability of comparative phylogeographic studies for the western Palearctic region makes it possible to distinguish general phylogeographic trends from specific interactions. Several shared phylogeographic breaks in Heligmosomoides and in A. sylvaticus in Western Europe are also found in other co-occurring invertebrate or vertebrate species. They include the Pyrenees limiting gene flow between Spain and Northern West Europe and the Alps isolating Italian populations. Although the presence of usual phylogeographic breaks does not exclude co-differentiation between Heligmosomoides and its host, co-differentiation might not be the most likely cause of these interruptions. In contrast, other phylogeographic breaks shared by Heligmosomoides and A. sylvaticus in South Western Europe do not correspond to phylogeographic breaks typically found in many other taxa: i.e., the differentiation of Sicily from continental Italy (even if few studies showed that Sicily is a hotspot of biodiversity in Europe (Randi et al., 2003; Fineschi et al., 2005; Fritz et al., 2005)), and the differentiation of Maghreb populations from Spain. These shared specific phylogeographic breaks are, in contrast to usual phylogeographic fractures, good clues arguing for long-term co-differentiation between the two species (Thompson, 2005). Third, this study confirmed that co-differentiation was significantly more likely than independent history between $A$. sylvaticus and Heligmosomoides in south Western Europe (TreEMAP analyses, Fig. 5, left).

These three arguments argue in favour of regional codifferentiation between Heligmosomoides and A. sylvaticus in south-western Europe (Spain, France and Belgium), North Africa, Italy and Sicily. The consequences of co-differentiation for the host and parasite histories have already been discussed elsewhere (Nieberding et al., 2004), except for North Africa. In North Africa, paleontological data attest the presence of the wood mouse since 10,000 years only (Dobson, 1998; Dobson and Wright, 2000). Libois et al. (2001) and Michaux et al. (2003) showed that North African A. sylvaticus reached North Africa via the Strait of Gibraltar as a result of anthropogenic introductions during the Holocene. Heligmosomoides phylogeographic data in this region confirms this scenario as the Moroccan parasite population clusters within the south western European clade 2. As $A$. sylvaticus is the only possible host species of Heligmosomoides in this region, these parasite data strongly suggest that colonization of North Africa by both species likely occurred from Spain.

\subsection{Regional co-differentiation between Heligmosomoides and A. flavicollis in the East}

In Eastern Europe, the parasite displays differentiated lineages in the Balkans and in Turkey, while the corresponding populations of $A$. sylvaticus remain undifferentiated from the Italian ones (Nieberding et al., 2006). Two relevant alternative host species for Heligmosomoides in these regions are $A$. flavicollis and $A$. mystacinus, because both species are abundant in the region and display a deep phylogeographic break between the Balkan and Turkish regions (Michaux et al., 2004, 2005a). Yet, this phylogeographic rupture is usual as the hedgehog Erinaceus concolor, the grasshopper Chorthippus parallelus, the Black alder Alnus glutinosa, the lesser white toothed shrew Crocidura suaveolens (reviewed in Hewitt, 1999), and more recently in Fraxinus angustifolia and in the brown trout Salmo trutta (Bardakci et al., 2006; Heuertz et al., 2006) display it too. Thus, the fracture between Balkan and Turkish populations is not in itself sufficient to argue for co-differentiation between Heligmosomoides and either A. flavicollis or A. mystacinus.

The TreeMap analyses revealed that it was more likely that Heligmosomoides co-differentiated in the East with A. flavicollis than with $A$. mystacinus (Fig. 5). This result is corroborated by two factors. First, A. mystacinus is absent from a large part of the distribution area covered by Heligmosomoides Balkan clade (Czech Republic, Slovakia, Slovenia), while in contrast A. flavicollis is and has been abundant in the region (Mitchell-Jones et al., 1999). Second, A. mystacinus displays two genetic lineages in Turkey, one of which colonized the island of Crete (Michaux et al., 2005a). In contrast, the Turkish populations of Heligmosomoides remain undifferentiated, and it was shown 
that the parasite colonized Crete from continental Greece (Nieberding et al., 2006).

However, the TREEMAP analysis of co-differentiation between Heligmosomoides and A. flavicollis is less conclusive than between the parasite and A. sylvaticus in South Western Europe (Fig. 5). The presence of a second Balkan genetic lineage in A. flavicollis, which was not observed in Heligmosomoides sampling, might partly explain this result (Michaux et al., 2004). We expect that additional sampling in Heligmosomoides eastern distribution range might reveal the additional Balkan lineage in the parasite.

\subsection{Relative abundance of host species might matter in parasite co-differentiation}

Currently, each Heligmosomoides lineage infects all Apodemus species present over its distribution range. The situation was likely similar during the Quaternary. During this period, each Apodemus species reacted uniquely to the climatic cycles, leading to unique phylogeographic patterns (Michaux et al., 2005b). Therefore, the long-term presence of Heligmosomoides in several Apodemus species in each regional lineage should have led ultimately to a mixed phylogeographic pattern in the parasite, obscuring the phylogeographic imprint of a particular host species.

Nevertheless, Heligmosomoides phylogeographic pattern mirrors regionally the phylogeography of two (and not more) Apodemus hosts across its distribution range, A. sylvaticus in the west and A. flavicollis in the east. How can this have happened? We suggest that regional differences in past and present abundance between Apodemus hosts could have led to the observed pattern of regional co-differentiation. In order to estimate the relative present abundances of Apodemus rodents in the western Palearctic, the sampling records of available field studies over the last 40 years were compiled (Table 2). This shows that $A$. sylvaticus is the dominant or even unique host species in those regions where Heligmosomoides mirrors its phylogeographic pattern, while A. flavicollis is predominant in Eastern Europe (proportion tests are highly significant; $p<2.2 \mathrm{e}^{-16}$; data from field missions in the Middle East remain too scarce to be included in the present summary). Recent estimations of $A$. sylvaticus and A. flavicollis local abundances point in the same direction: A. sylvaticus density is maximum in south western Europe (50 individuals per hectare), while A. flavicollis is absent from western France and much of the Iberian peninsula, has a limited distribution in the west and south, but has a density of over 100 ind/ha in Eastern Europe (Mitchell-Jones et al., 1999). Similarly, the compilation of Apodemus fossil records over Europe highlights that $A$. sylvaticus dominated south Western Europe in the past too (supplementary Table 2). The past predominant abundance of A. flavicollis in Eastern Europe appears less straightforward, although the southern part of the Balkans was relatively richer in A. flavicollis than the northern Balkans, which is in agreement with the long-term survival of $A$. flavicollis in the south (Michaux et al., 2004). Therefore, past and present predominance of A. sylvaticus in south Western Europe and in North Africa might be responsible for the local phylogeographic similarity between its phylogeography and the one of Heligmosomoides, despite the parasite presence in other Apodemus. The present and possibly past predominance of $A$. flavicollis in Eastern Europe might similarly explain the significant, but less strong, pattern of co-differentiation between its regional phylogeographic structure and the one of Heligmosomoides.

\subsection{Northern refuge for Heligmosomoides Polish populations?}

It is worth mentioning that Heligmosomoides displays a distinct and highly differentiated (since around $1.8 \mathrm{Myr}$ ago) clade in Poland and extends into Russia (Fig. 1). Similarly, some species such as the brown bear (Ursus arctos) (Taberlet et al., 1998) or different small mammal species [Clethrionomys glareolus (Deffontaine et al., 2005); Sorex minutus and S. araneus (Bilton et al., 1998) and M. arvalis (Jaarola and Searle, 2004) and M. oeconomus (Brunhoff et al., 2003)] display genetic lineages suggesting that these species also survived in more easterly refuges (the Caucasus or the southern Urals) and in Central Europe (Kotlrk et al., 2006). Moreover, the examination of the fossil record of European temperate species during the last ice age (26000-13000 years ago) reveals that environmental conditions were not severe enough in these regions to prevent the survival of forest-dependent species, notably in Poland (Sommer and Nadachowski, 2006). Thus the model of exclusively southern glacial refuges in Europe becomes more and more limited as phylogeographic studies accumulate in north Eastern Europe.

\section{Conclusion}

Here we tested whether host specificity or geography played a role in structuring the parasite phylogeography. Thus, the parasite shows no specificity (i.e., has no lineages that segregate among host species), and geography, which is the usual cause of genetic structuring for most organisms, explains most of the parasite structuring. Yet, in areas where there is one dominant host species for long evolutionary periods, the parasite shows congruence with host phylogeography. This indicates likely co-differentiation with the host. Therefore, both geography and host phylogeography are important in determining Heligmosomoides phylogeographic structure.

Co-differentiation is expected to lead to co-speciation over a longer time period. Yet, this study suggests that co-speciation might not be observed at a higher phylogenetic scale (i.e., over a longer time period) if host specificity is not limited to a single host species. Indeed, regional codifferentiation with different closely related host species might rather ultimately mix the co-differentiation signal if the different host species overlap partially in their distribu- 
tion ranges and if the parasite life history traits, such as in Heligmosomoides, authorize host switching events between syntopic host species (Weckstein, 2004). In addition, the signal of regional co-differentiation, if generated by differences in the regional abundance of the different hosts, might also be lost if the relative regional host abundance changes over evolutionary time. This is likely to occur when considering the amplitude of climatic changes typical of the last two million years (VanAndel and Tzedakis, 1996; Hewitt, 1999). Third, invasion of new hosts may also disrupt co-differentiation patterns. Therefore, we expect that the high number of strictly co-evolving host-parasite interactions described at the population level (for a review, see Whiteman and Parker, 2005; Wirth et al., 2005; Nieberding and Olivieri, 2007) might not lead to co-speciation between these host and parasite groups over a longer time period. In agreement with this idea, studies showing actual host-parasite co-speciation patterns remain rare among the many studies that compared host and parasite phylogenies (Page, 2003; Charleston and Perkins, 2006).

\section{Acknowledgments}

We thank F. Audebert, S. Caro, R. Fons, J. Goüy de Bellocq, H. Henttonen, F. Hourlay, P. Lymberakis, E. Magnanou, J. Miquel, P. Perret and A. Orth for providing Heligmosomoides or Apodemus gut samples, for morphological determination or for logistical help, N. Charbonnel, J.-F. Cosson and J. Deter for field sampling information; Y. Desdevises for friendly pieces of advice and two anonymous referees for very useful and constructive comments on an earlier version of the ms. This work was supported by a Belgian Fonds National de la Recherche Scientifique fellowship to C.N. (mandats "aspirant" et "Chargé de Recherches") and V.D. (mandat "aspirant") and to J.R.M. and A.V. (mandat 'chercheur qualifié"), a financial Grant of the Belgian FNRS (crédits pour brefs séjours à l'étranger to C.N. and R.L.), from the University of Liège (Patrimoine), from the Institut Francais de la Biodiversité (IFB), and from the Government of Catalogne (project 2005-SGR-00576).

\section{Appendix A. Supplementary data}

Supplementary data associated with this article can be found, in the online version, at doi:10.1016/j.ympev. 2008.01.028.

\section{References}

Agnelli, P., Bellini, L., 1997. Alcuni aspetti della biologia di Apodemus sylvaticus e Apodemus flavicollis: un caso di simpatria in Italia centrale. Bolletino del Museo Regionale di Scienze Naturali Torino 15, 213-224.

Arrizabalaga, A., Torre, I., Catzeflis, F., Renaud, F., Santalla, F., 1999. Primera citació d'Apodemus flavicollis (Melchior, 1834) al Montseny. Determinació morfològica i genètica. III i IV trobades d'estudiosos del Montseny. Monografies 27, 193-195.
Asakawa, M., Bertouille, E., Reutter, B.A., Vogel, P., 1999. Parasitic nematodes of Apodemus alpicola (Mammalia: Rodentia: Muridae) collected in Switzerland. Helminthologia 36, 287-289.

Avise, J.C., Walker, D., Johns, G.C., 1998. Speciation durations and Pleistocene effects on vertebrate phylogeography. Proc. R. Soc. Lond. B 265, 1707-1712.

Ballard, J.W.O., Whitlock, M.C., 2004. The incomplete natural history of mitochondria. Mol. Ecol. 13, 729-744.

Barciová, L., Macholán, M., 2006. Morphometric study of two species of wood mice Apodemus sylvaticus and A. flavicollis (Rodentia: Muridae): traditional and geometric morphometric approach. Acta Theriol. 51, $15-27$.

Bardakci, F., Degerli, N., Ozdemir, O., Basibuyuk, H.H., 2006. Phylogeography of the Turkish brown trout Salmo trutta L.: mitochondrial DNA PCR-RFLP variation. J. Fish Biol. 68, 36-55.

Bilton, D.T., Mirol, P.M., Mascheretti, S., Fredga, K., Zima, J., Searle, J.B., 1998. Mediterranean Europe as an area of endemism for small mammals rather than a source for northwards postglacial colonization. Proc. R. Soc. Lond. B 265, 1219-1226.

Blaxter, M.L., De Ley, P., Garey, J.R., Liu, L.X., Scheldeman, P., Vierstraete, A., Vanfleteren, J.R., Mackey, L.Y., Dorris, M., Frisse, L.M., Vida, J.T., Thomas, W.K., 1998. A molecular evolutionary framework for the phylum Nematoda. Nature 392, 71-75.

Brunhoff, C., Galbreath, K.E., Fedorov, V.B., Cook, J.A., Jaarola, M., 2003. Holarctic phylogeography of the root vole (Microtus oecono$m u s$ ): implications for late quaternary biogeography of high latitudes. Mol. Ecol. 12, 957-968.

Butet, A., Paillat, G., Delettre, Y., 2006. Seasonal changes in small mammal assemblages from field boundaries in an agricultural landscape of western France. Agric. Ecosyst. Environ. 113, 364-369.

Canova, L., 1992. Distribution of habitat preference of small mammals in a biotope of the north Italian plain. Boll. Zool. 59, 417-421.

Charleston, M.A., Perkins, S.L., 2006. Traversing the tangle: algorithms and applications for cophylogenetic studies. J. Biomed. Inform. 39, 62 71.

Cordy, J.M., 1984. Evolution des faunes quaternaires en Belgique. In: Cahen, D., Haesaerts, P. (Eds.), Peuples chasseurs de la Belgique prehistorique dans leur cadre naturel. Bruxelles, pp. 67-77.

Deffontaine, V., Libois, R., Kotlik, P., Sommer, R., Nieberding, C., Paradis, E., Searle, J.B., Michaux, J.R., 2005. Beyond the Mediterranean peninsulas: evidence of central European glacial refugia for a temperate forest mammal species, the bank vole (Clethrionomys glareolus). Mol. Ecol. 14, 1727-1739.

de la Pena, N.M., Butet, A., Delettre, Y., Paillat, G., Morant, P., Le Du, L., Burel, F., 2003. Response of the small mammal community to changes in western French agricultural landscapes. Landscape Ecol. $18,265-278$.

Dobson, M., 1998. Mammal distribution in the western Mediterranean: the role of human intervention. Mammal Rev. 28, 77-88.

Dobson, M., Wright, A., 2000. Faunal relationships and zoogeographical affinities of mammals in north-west Africa. J. Biogeogr. 27, 417-424.

Durette-Desset, M.-C., 1968. Identification des Strongles des Mulots et Campagnols décrits par Dujardin. Annales de Parasitologie 43, $387-$ 404.

Edwards, S.V., Beerli, P., 2000. Perspective: gene divergence, population divergence, and the variance in coalescence time in phylogeographic studies. Evolution 54, 1839-1854.

Ehrenford, F.A., 1954. The life cycle of Nematospiroides dubius Baylis (Nematoda: Heligmosomidae). J. Parasitol. 40, 480-481.

Fernandes, C., Engels, H., Abade, A., Coutinho, M., 1991. Zur genetischen und morphologischen variabilität der gattung Apodemus (Muridae) in weatern der Iberishen Halbinsel. Bonn. Zool. Beitr. 42, 261269.

Filippucci, M.G., Macholan, M., Michaux, J.R., 2002. Genetic variation and evolution in the genus Apodemus (Muridae: Rodentia). Biol. J. Linn. Soc. Lond. 75, 395-419.

Fineschi, S., Cozzolino, S., Migliaccio, M., Musacchio, A., Innocenti, M., Vendramin, G.G., 2005. Sicily represents the Italian reservoir of 
chloroplast DNA diversity of Quercus ilex L. (Fagaceae). Ann. For. Sci. 62, 79-84.

Fritz, U., Fattizzo, T., Guicking, D., Tripepi, S., Pennisi, M.G., Lenk, P., Joger, U., Wink, M., 2005. A new cryptic species of pond turtle from southern Italy, the hottest spot in the range of the genus Emys (Reptilia, Testudines, Emydidae). Zool. Scr. 34, 351-371.

Heuertz, M., Carnevale, S., Fineschi, S., Sebastiani, F., Hausman, J.F., Paule, L., Vendramin, G.G., 2006. Chloroplast DNA phylogeography of European ashes, Fraxinus sp (Oleaceae): roles of hybridization and life history traits. Mol. Ecol. 15, 2131-2140.

Hewitt, G.M., 1999. Post-glacial re-colonization of European biota. Biol. J. Linn. Soc. Lond. 68, 87-112.

Huelsenbeck, J.P., Rannala, B., Yang, Z., 1997. Statistical tests of hostparasite cospeciation. Evolution 51, 410-419.

Humair, P.F., Peter, O., Wallich, R., Gern, L., 1995. Strain variation of Lyme-disease spirochetes isolated from Ixodes-Ricinus ticks and rodents collected in 2 endemic areas in Switzerland. J. Med. Entomol. $32,433-438$.

Jaarola, M., Searle, J.B., 2004. A highly divergent mitochondrial DNA lineage of Microtus agrestis in southern Europe. Heredity 92, 228-234.

Kass, R.E., Raftery, A.E., 1995. Bayes factors. J. Am. Stat. Assoc. 90, 773-795.

Kotlík, P., Deffontaine, V., Mascheretti, S., Zima, J., Michaux, J.R., Searle, J.B., 2006. A northern glacial refugium for bank voles (Clethrionomys glareolus). Proc. Natl. Acad. Sci. USA 103, 1486014864.

Kowalski, K., 2001. Pleistocene rodents of Europe. Folia Quaternaria 72, $1-389$.

Libois, R., Michaux, J., Ramalhinho, M.G., Maurois, C., Sara, M., 2001. On the origin and systematics of the northern African wood mouse (Apodemus sylvaticus) populations: a comparative study of mtDNA restriction patterns. Can. J. Zool. 79, 1503-1511.

Michaux, J.R., Kinet, S., Filippucci, M.-G., Libois, R., Besnard, A., Catzeflis, A., 2001. Molecular identification of three sympatric species of wood mice (Apodemus sylvaticus, A. flavicollis, A. alpicola) in Western Europe (Muridae: Rodentia). Mol. Ecol. Notes 1, 260263

Michaux, J.R., Chevret, P., Filippucci, M.G., Macholan, M., 2002. Phylogeny of the genus Apodemus with a special emphasis on the subgenus Sylvaemus using the nuclear IRBP gene and two mitochondrial markers: cytochrome b and $12 \mathrm{~S}$ rRNA. Mol. Phylogenet. Evol. $23,123-136$.

Michaux, J.R., Magnanou, E., Paradis, E., Nieberding, C., Libois, R., 2003. Mitochondrial phylogeography of the Woodmouse (Apodemus sylvaticus) in the Western Palearctic region. Mol. Ecol. 12, 685-697.

Michaux, J.R., Libois, R., Paradis, E., Filippucci, M.G., 2004. Phylogeographic history of the yellow-necked fieldmouse (Apodemus flavicollis) in Europe and in the Near and Middle East. Mol. Phylogenet. Evol. 32, 788-798.

Michaux, J., Bellinvia, E., Lymberakis, P., 2005a. Taxonomy, evolutionary history and biogeography of the broad-toothed field mouse (Apodemus mystacinus) in the eastern Mediterranean area based on mitochondrial and nuclear genes. Biol. J. Linn. Soc. 85, 53-63.

Michaux, J.R., Libois, R., Filippucci, M.G., 2005b. So close and so different: comparative phylogeography of two small mammal species, the yellow-necked fieldmouse (Apodemus flavicollis) and the Woodmouse (Apodemus sylvaticus) in the Western Palearctic region. Heredity $94,52-63$.

Milazzo, C., 2001. Estudio faunistico y ecologico de las helmintofaunas parasitas de Apodemus spp. en Calabria (sur de Italia). Ph.D. thesis, University of Barcelona (Spain).

Mitchell-Jones, A.J., Amori, G., Bogdanowicz, W., Krystufek, B., Reijnders, P.J.H., Spitzenberger, F., Stubbe, M., Thissen, J.B.M., Vohralik, V., Zima, J., 1999. The Atlas of European Mammals. T and AD Poyser Ltd, London.

Nieberding, C., Morand, S., Libois, R., Michaux, J.R., 2004. A parasite reveals cryptic phylogeographic history of its host. Proc. R. Soc. Lond. B 271, 2559-2568.
Nieberding, C., 2005a. Comparative phylogeography of the woodmouse Apodemus sylvaticus and of its parasite Heligmosomoides polygyrus in the western Palearctic region: the use of a parasite to get insight in its host evolutionary history. Ph.D. thesis, University of Liège, 219 p.

Nieberding, C., Libois, R., Douady, C.J., Morand, S., Michaux, J.R., 2005b. Phylogeography of a nematode (Heligmosomoides polygyrus) in the western Palearctic region: persistence of northern cryptic populations during ice ages? Mol. Ecol. 14, 765-779.

Nieberding, C., Morand, S., Libois, R., Michaux, J.R., 2006. Parasites and the island syndrome: the colonization of the western Mediterranean islands by Heligmosomoides polygyrus (Dujardin, 1845). J. Biogeogr. 33, 1212-1222.

Nieberding, C., Olivieri, I., 2007. Parasites: proxies for host genealogy or ecology? Trends Ecol. Evol. 22, 156-165.

N'Zobadila, G., Boyer, J., Vuong, P.N., Durette-Desset, M.-C., 1996a. Morphogenèse d'Heligmosomoides polygyrus polygyrus (Dujardin, 1845) (Trichostongylina-Heligmonelloidea) chez Apodemus flavicollis en France. Comparaison avec les espèces proches Heligmosomoides laevis (Dujardin, 1845) et Heligmosomum mixtum Schulz, 1926, parasites d'Arvicolidae. Bull. Mus. Paris 4ème sér. $18 \mathrm{~A}, 73-91$.

N'Zobadila, G., Boyer, J., Vuong, P.N., Durette-Desset, M.-C., 1996b. Chronologie du cycle et étude des pseudo-kystes d'Heligmosomoides polygyrus polygyrus (Dujardin, 1845) (Trichostongylina-Heligmonelloidea) chez Apodemus flavicollis en France. Comparaison avec les espèces proches. Parasite 3, 237-246.

Page, R.D.M., 1994. Parallel phylogenies: reconstructing the history of host-parasite assemblages. Cladistics 10, 155-173.

Page, R.D.M., 2003. Tangled Trees: Phylogeny, Cospeciation, and Coevolution. University of Chicago Press.

Pagel, M., Meade, A., 2004. A phylogenetic mixture model for detecting pattern-heterogeneity in gene sequence or character-state data. Syst. Biol. 53, 571-581.

Panteleyev, A., 1998. The rodents of the Palaearctic fauna: composition and areas. Moscow: A.N. Severtzov IEE of RAS.

Prokopic, J., 1972. Biocenotical study on cestodes of small mammals in various biotopes. Acta Sc Nat Brno 6, 1-68.

Raftery, A.E., 1996. Hypothesis testing and model selection. In: Gilks, W.R., Richardson, S., Spiegelhalter, D.J. (Eds.), Markov Chain Monte Carlo in Practice. Chapman \& Hall, London, pp. 163-187.

Randi, E., Tabarroni, C., Rimondi, S., Lucchini, V., Sfougaris, A., 2003. Phylogeography of the rock partridge (Alectoris graeca). Mol. Ecol. 12, 2201-2214.

Ribas, A., Casanova, J.C., Goüy de Bellocq, J., Feliu, C., 2004. Helminth fauna of a sympatric population of Apodemus sylvaticus and $A$. flavicollis (Rodentia, Muridae) in the Natural Park of Montseny (Spain). In: IX european multicolloquium of parasitology, Valencia, Spain.

Sainz-Elipe, S., Galicia, D., Imaz, A., Galán-Puchades, M.T., Fuentes, M.V., 2004. The helminth community of small mammals (Rodentia: Muridae) in the Mediterranean biogeographical region of Navarra (Spain). II. Helminthfauna of Apodemus sylvaticus and Apodemus flavicollis in the Erro river valley. In: IX european multicolloquium of Parasitology, Valencia, Spain.

Schluter, D., 2001. Ecology and the origin of species. Trends Ecol. Evol. $16,372-380$.

Sese, C., 1994. Paleoclimatical interpretation of the quaternary small mammals of Spain. Geobios 27, 753-767.

Sibold, C., Ulrich, R., Labuda, M., Lundkvist, A., Martens, H., Schutt, M., Gerke, P., Leitmeyer, K., Meisel, H., Kruger, D.H., 2001. Dobrava hantavirus causes hemorrhagic fever with renal syndrome in central Europe and is carried by two different Apodemus mice species. J. Med. Virol. 63, 158-167.

Sommer, R.S., Nadachowski, A., 2006. Glacial refugia of mammals in Europe: evidence from fossil records. Mammal Rev. 36, 251-265.

Stanko, M., Miklisova, D., de Bellocq, J.G., Morand, S., 2002. Mammal density and patterns of ectoparasite species richness and abundance. Oecologia 131, 289-295. 
Stefancikova, A., Gajdos, O., Kazimir, J.K., Tomasovicova, O., 1994. Helminth fauna of small mammals in the urban and suburban area of Kosice. Biologia Bratislava 49, 147-152.

Taberlet, P., Fumagalli, L., Wust-Saucy, A.G., Cosson, J.F., 1998. Comparative phylogeography and postglacial colonization routes in Europe. Mol. Ecol. 7, 453-464.

Tenora, F., Barus, V., Prokes, M., 2003. Notes to the species Heligmosomoides polygyrus (Dujardin, 1845) (Nematoda, Heligmosomidae), parasitizing rodentia. Acta Universitatis Agriculturae et Sylviculturae Mendelianae Brunensis 1, 7-18.

Thompson, J.N., 2005. The geographic mosaic of coevolution. University of Chicago Press.

VanAndel, T.H., Tzedakis, P.C., 1996. Palaeolithic landscapes of Europe and environs, $150,000-25,000$ years ago: an overview. Quaternary Sci. Rev. 15, 481-500.

Vostal, K., Zakovska, A., 2003. Two-year study of examination of blood from wild rodents for the presence of antiborrelian antibodies. Ann. Agric. Environ. Med. 10, 203-206.
Vukicevic-Radic, O., Matic, R., Kataranovski, D., Stamenkovic, S., 2006. Spatial organization and home range of Apodemus flavicollis and A. agrarius on mt. Avala, Serbia. Acta Zool. Acad. Sci. H 52, 81-86.

Weckstein, J.D., 2004. Biogeography explains cophylogenetic patterns in toucan chewing lice. Syst. Biol. 53, 154-164.

Whiteman, N.K., Parker, P.G., 2005. Using parasites to infer host population history: a new rationale for parasite conservation. Anim. Conserv. 8, 175-181.

Wirth, T., Meyer, A., Achtman, M., 2005. Deciphering host migrations and origins by means of their microbes. Mol. Ecol. 14, 3289-3306.

Zeman, P., Daniel, M., 1999. Mosaic pattern of Borrelia infection in a continuous population of the tick Ixodes ricinus (Acari: Ixodidae). Exp. Appl. Acarol. 23, 327-335.

Zeman, P., Januska, J., 1999. Epizootiologic background of dissimilar distribution of human cases of Lyme borreliosis and tick-borne encephalitis in a joint endemic area. Comp. Immunol. Microbiol. Infect. Dis. 22, 247-260. 